МИНИСТЕРСТВО НАУКИ И ВЫСШЕГО ОБРАЗОВАНИЯ РФ

ФЕДЕРАЛЬНОЕ ГОСУДАРСТВЕННОЕ БЮДЖЕТНОЕ ОБРАЗОВАТЕЛЬНОЕ УЧРЕЖДЕНИЕ

ВЫСШЕГО ОБРАЗОВАНИЯ «КЕМЕРОВСКИЙ ГОСУДАРСТВЕННЫЙ УНИВЕРСИТЕТ "

БЕЛОВСКИЙ ИНСТИТУТ (ФИЛИАЛ)

\title{
OCHOBbl nCnxonornn
}

(учебное пособие

для непрофильных специальностей)

Авт.-сост.: Долганов Д.Н. 
МИНИСТЕРСТВО НАУКИ И ВЫСШЕГО ОБРАЗОВАНИЯ РФ ФЕДЕРАЛЬНОЕ ГОСУДАРСТВЕННОЕ БЮДЖЕТНОЕ ОБРАЗОВАТЕЛЬНОЕ УЧРЕЖДЕНИЕ ВЫСШЕГО ОБРАЗОВАНИЯ «КЕМЕРОВСКИЙ ГОСУДАРСТВЕННЫЙ УНИВЕРСИТЕТ» БЕЛОВСКИЙ ИНСТИТУТ (ФИЛИАЛ)

\section{Основы психологии}

(учебное пособие для непрофильных специальностей)

Автор-составитель: Д.Н. Долганов 


\title{
УДК 159.9(075.8)
}

ББК 88 я73

O-75

Печатается по решению методического совета

Кемеровского государственного университета

\section{Рецензенты:}

Кафедра гуманитарных наук БИФ КемГУ;

\begin{abstract}
А.А. Утюганов, доктор психологических наук, доцент, начальник кафедры гуманитарных и социальных наук ФГКВОУ ВО «Новосибирский военный институт имени генерала армии И.К. Яковлева войск национальной гвардии Российской Федерации»
\end{abstract}

Основы психологии (учебное пособие для непрофильных 0-75 специальностей) / авт.-сост.: Д.Н. Долганов; Беловский институт (филиал) федерального государственного бюджетного образовательного учреждения высшего образования «Кемеровский государственный университет» [Электронный ресурс]. - Электрон. текстовые дан. - Красноярск: НИЦ, 2021. - 60 с. - Режим доступа: http://nkras.ru/arhiv/2021/DolganovDN.pdf - Систем. требования: IBM PC; Internet Explorer и др; Acrobat Reader 3.0 или старше.

\section{ISBN 978-5-907208-53-7 \\ DOI: 10.12731/978-5-907208-53-7}

Пособие содержит краткий теоретический материал и задания для самостоятельной работы по основным темам дисциплин «Психология», «Основы психологии» читаемых студентам специальностей «Экономика и управление», «Менеджмент», «Юриспруденция». Рекомендуется студентам для использования в учебных целях.

Автор-составитель: Д.Н. Долганов

Свидетельство о регистрации

электронного издания сетевого распространения № 2042, зарегистрировано ФГУП НТЦ «Информрегистр» «16» марта 2021 г. и ему присвоен номер регистраџии 0522100163.

ISBN 978-5-907208-53-7

(C) Кемеровский государственный университет, 2021

(С) Долганов Д.Н., 2021

(c) Оформление.

Научно-инновационный центр, 2021 


\section{СОДЕРЖАНИЕ}

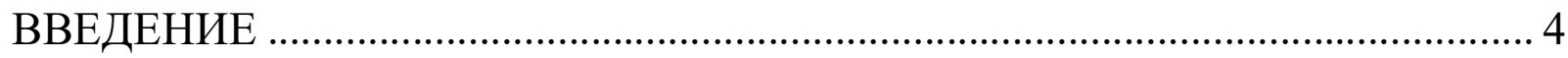

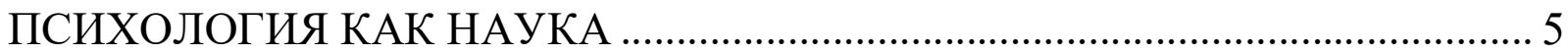

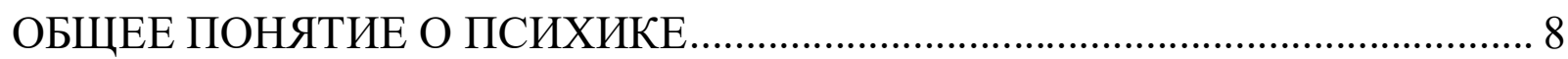

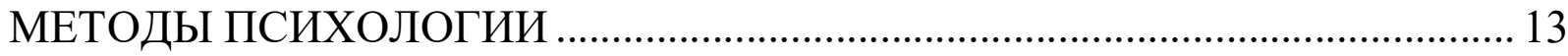

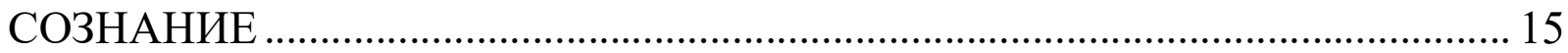

ПОВЕДЕНИЕ И ДЕЯТЕЛЬНОСТЬ ЧЕЛОВЕКА .................................................. 19

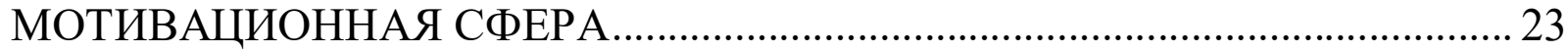

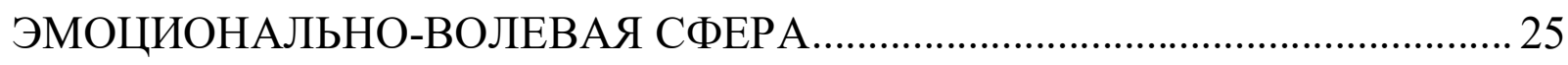

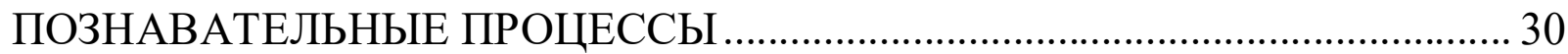

ПРОБЛЕМА ЛИЧНОСТИ В ПСИХОЛОГИИ......................................................... 34

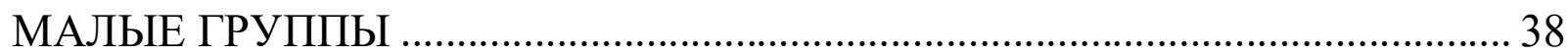

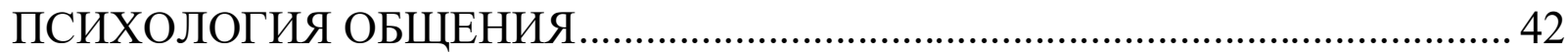

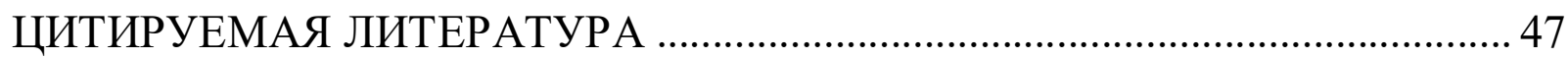

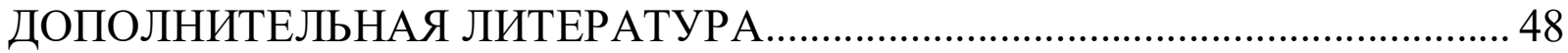




\section{ВВЕДЕНИЕ}

На специальностях «Экономика», «Менеджмент», «Юриспруденция», в соответствии с учебными планами предусмотрена дисциплина «Основы психологии» или «Психология». В рамках данной дисциплины, студенты непрофильных специальностей должны ознакомиться с основными понятиями и категориями психологической науки. Рассмотреть ряд вопросов необходимых им в дальнейшем при реализации профессиональной деятельности. А также необходимых для взаимодействия с коллегами в трудовых коллективах.

В рамках курса студенты знакомятся с базовым понятием «психика» и историей становления предмета психологической науки. Рассматриваются основные проявления психики: психические процессы, психические состояния и психические свойства. Рассматриваются вопросы о структуре и механизмах функционирования малых социальных групп, и основы психологии общения.

В дополнение к основным самостоятельным работам по курсу размещенных в электронной образовательной среде институт, данное учебное пособие предлагает ряд заданий. Выполнение данных задний предполагает проявление активности в работе с материалом. Задания предполагают проявление рефлексии по отношению к собственному житейскому опыту, профессиональной деятельности, a также проявление проспективной рефлексии в отношении будущей профессиональной деятельности.

Пособие содержит краткую информацию по основным темам курса, рекомендуемую литературу и задания для самостоятельной. 


\section{ПСИХОЛОГИЯ КАК НАУКА}

Психология, как и другие науки имеет собственный предмет исследования. Формирование представлений о предмете науки складывались на протяжении многовековой истории философской мысли. Психология и очень старая, и совсем молодая наука. Данный «парадокс» объясняется тем, что развитие науки складывается из двух больших этапов: первый донаучный (философский) и второй - научный, когда психология оформилась в качестве самостоятельной научной дисциплины.

Все психологические представления могут быть представлены либо на уровне житейском, либо на уровне научном.

Таблица 1. Сравнение житейских и научных психологических знаний [7]

\begin{tabular}{|l|l|l|}
\hline Критерии & Житейская психология & Научная психология \\
\hline Психологическе факты & Конкретны & Обобщенные \\
\hline Психологические знания & Интуитивные & $\begin{array}{l}\text { Рациональны } \\
\text { осознаны }\end{array}$ \\
\hline Передача знаний & Затруднена & Без ограничений \\
\hline $\begin{array}{l}\text { Методы получения } \\
\text { знаний }\end{array}$ & Наблюдение & Эксперимент \\
\hline $\begin{array}{l}\text { Наличный фактический } \\
\text { материал }\end{array}$ & Ограничен & Обширный \\
\hline
\end{tabular}

Не смотря на имеющиеся «ограничения» житейских психологических знаний, они выполняют весьма важную функцию в процессе порождения научного знания. С одной стороны, житейские знания (опыт) являются источником проблемных задач, которые становиться предметом научных исследований. С другой стороны, любое научное знание, в конечном итоге проходит проверку на уровне житейского опыта. Есть еще один аспект, как указывает В.Н. Дружинин, житейские представления являются «мостиком» для перевода научных понятий из одного научного подхода, в другой [4]. 
Психология - это наука, которая имеет достаточно объемную историю своего развития. Развитие основных психологических идей осуществлялось на протяжении нескольких этапов. На одном из них психологические знания формировались в рамках философии, затем произошло выделение психологии в самостоятельную область знания. И даже оформившись в качестве самостоятельной дисциплины, способы и подходы к описанию психологической реальности много раз трансформировались и вступали в противоречие друг с другом. Подобные проявления носят не случайный характер. Психика - конструкт абстрактный, многогранный, динамичный. Мы не можем взять его в руки, измерить линейкой и т.п. Наши проявления психики меняются в контексте изменений внешнего мира. В связи с чем, в психологии можно обнаружить достаточное количество объяснений, что такое психика, и как бы парадоксально это не звучало, все они верные. Ниже в схеме приведены основные вехи становления психологии.

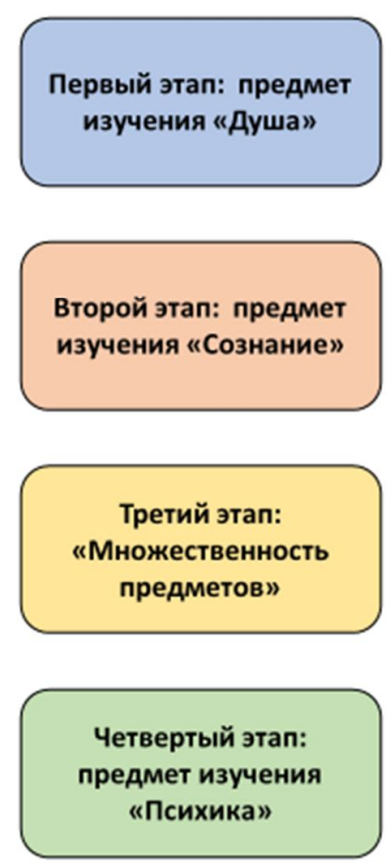

- Античный период; Средние века; Эпоха возрождения.

- Вводиться понятие рефлекса (Р. Декарт)

\section{- Вводиться понятиерефлекса (Р. Декарт)}

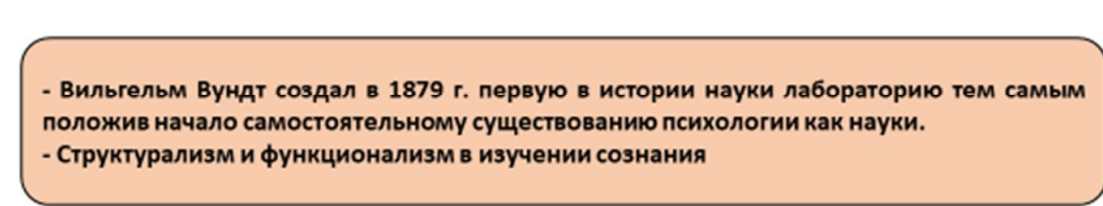
положив начало самостоятельному существованию психологии как науки.

- Структурализм и функционализм в изучении сознания

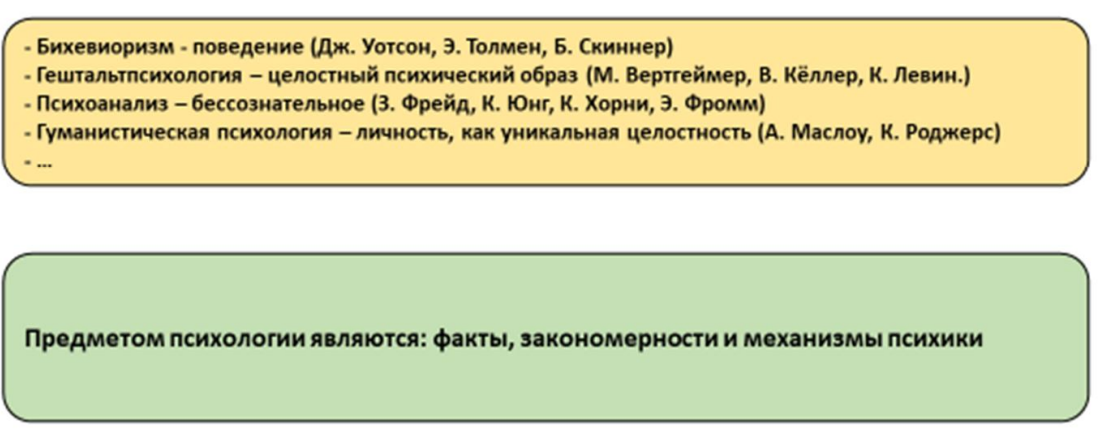

Рисунок 1. Этапы становления психологических идей

Рекомендуемая литература для самоподготовки 
Гуревич, П. С. Психология : учебник для вузов / П. С. Гуревич. - 2-е изд., перераб. и доп. - Москва : Издательство Юрайт, 2020. - 465 с. (Высшее образование). — ISBN 978-5-9916-5042-7. — Текст : электронный // ЭБС Юрайт [сайт]. — URL: https://urait.ru/bcode/449915

Лебедев, А. Н. Психология для экономистов : учебник и практикум для вузов / А. Н. Лебедев. - Москва : Издательство Юрайт, 2020. - 328 с. (Высшее образование). - ISBN 978-5-9916-5093-9. — Текст : электронный // ЭБС Юрайт [сайт]. — URL: https://urait.ru/bcode/450257

Психология : учебник и практикум для вузов / А. С. Обухов [и др.] ; под общей редакцией А. С. Обухова. - 2-е изд., перераб. и доп. - Москва : Издательство Юрайт, 2020. - 404 с. - (Высшее образование). ISBN 978-5-534-00631-5. - Текст : электронный // ЭБС Юрайт [сайт]. URL: https://urait.ru/bcode/449860

\section{Задания для самостоятельной работы}

1. Составить схему (таблицу) основные достижения на каждом из этапов развития психологии

2. Приведите примеры проявления житейских знаний (из собственного опыта, наблюдений за знакомыми и т.п.)

3. Перечислите основные кризисные периоды в развитии психологии и назовите их основные причины. 


\section{ОБЩЕЕ ПОНЯТИЕ О ПСИХИКЕ}

Общепринятое понятие гласит: психика - это системное свойство высокоорганизованной материи, заключающееся в активном отражении субъектом объективного мира, в построении неотчуждаемой от него картины этого мира и саморегуляции на этой основе своего поведения и деятельности.

О чем нам говорит данное определение. Во-первых, психика - это система. А что такое система? Под системой мы понимаем не сводимую к арифметической сумме совокупность элементов. Следовательно система это не просто какое-то количество элементов, но в первую очередь - это связи и отношения между данными элементами. Ведь психика любого человека включает набор однотипных элементов: бессознательные и осознаваемые процессы, когнитивные, эмоциональные и пр. процессы. Но ведь нет двух одинаковых людей. И именно в этом мы видим проявление системности психики. И уж тем более очевидным значение связей и отношений между элементами мы видим на примере сравнения людей с нормальной и нарушенной психикой. Во-вторых, психика есть свойство высокоорганизованной материи, о чем еще будет сказано ниже. В-третьих, активное отражение мира можно понимать следующим образом. Воспринимает человек посредством органов чувств. В-четвертых, образ отражаемой действительности является неотчуждаемым. Неотчуждаемость мы понимаем в том смысле, что содержание психического образа неотделимы от субъекта и связаны с ним. Например, различные телесные ощущения неразрывно связаны с нашим телом. И в-пятых, данная структура отражения окружающей действительности имеет четкое функциональное назначение регуляция и саморегуляция активности. 
Психика - это способность отражать. Отражение - это всеобщее свойство материи, заключающееся в воспроизведении особенностей отражаемого объекта или процесса.

Таблица 2. Особенности психического отражения и свойства психического образа

\begin{tabular}{|c|c|}
\hline Особенности психического отражения & Свойства психического образа \\
\hline $\begin{array}{l}\text { 1. Принадлежность индивиду, субъекту всего } \\
\text { того, что он отражает (испытывает) }\end{array}$ & 1. Образ обладает идеальностью \\
\hline $\begin{array}{l}\text { 2. Психика отражает объективную реальность, } \\
\text { существующую вне и независимо от нее }\end{array}$ & 2. Образ субъективен \\
\hline \multirow{2}{*}{$\begin{array}{l}\text { 3. При физическом отражении происходит } \\
\text { изменение взаимодействующих предметов, } \\
\text { веществ, а при психическом отражении - } \\
\text { материальный мир не меняется, происходят } \\
\text { изменения только внутреннего психического } \\
\text { мира }\end{array}$} & 3. Образ объективен \\
\hline & $\begin{array}{l}\text { 4. Образ демонстрирует неполноту } \\
\text { отражения }\end{array}$ \\
\hline
\end{tabular}

Описывая основные формы проявления психики, принято выделять следующие основные формы (таблица 3)

Таблица 3. Формы проявления психики

\begin{tabular}{|c|c|c|}
\hline Формы & Содержание & Особенности \\
\hline Психические процессы & $\begin{array}{l}\text { Познавательные } \\
\text { мотивационные поцессы; } \\
\text { процесс рефлексии; волессы, } \\
\text { процессы. }\end{array}$ & $\begin{array}{l}\text { Процессы }- \text { это } \\
\text { динамичные явления. }\end{array}$ \\
\hline Психические свойства & $\begin{array}{lr}\text { Свойства } & \text { личности; черты } \\
\text { характера; } & \text { особенности } \\
\text { темперамента; } & \text { способности; } \\
\text { направленность личности. }\end{array}$ & $\begin{array}{l}\text { Свойства }- \text { это } \\
\text { достаточно } \\
\text { устойчивые явления. }\end{array}$ \\
\hline Психические состояния & $\begin{array}{ll}\text { Эмоциональные } & \text { состояния; } \\
\text { мотивационные } & \text { состояния; } \\
\text { волевые состояния. } & \end{array}$ & $\begin{array}{l}\text { Психические } \\
\text { состояния - это режим } \\
\text { деятельности человека }\end{array}$ \\
\hline
\end{tabular}




\section{Филогенез и онтогенез психики}

Рассматривая вопрос о происхождении и развитии психики, нужно учитывать следующую терминологию:

Филогенез психики - (от греч. Phyle - род, племя, вид и genos происхождение) - это процесс возникновения и исторического развития психики и поведения животных, возникновения и эволюции форм сознания в ходе истории человечества.

Онтогенез - (от греч. - ontos - сущее) - процесс развития индивидуального организма. Изучается формирование основных структур психики индивида от зачатия до смерти.

\section{Концепция Леонтьева-Фабри}

А.Н. Леонтьев высказал гипотезу о происхождении психики, в основе которой лежит критерий чувствительности. Под чувствительностью понимается способность живого организма реагировать на раздражители. В соответствии с данной гипотезой выделяются следующие уровни проявления психики: 1. Уровень сенсорной психики - предполагает отражение только отдельных свойств предметов (ощущения); 2. Уровень перцептивной психики - отражение целостного объекта (восприятие); 3. Уровень интеллектуальной психики - решение сложных задач и перенос найденного способа решения в аналогичные условия. В дальнейшем, К.Э. Фабри, опираясь на данные зоопсихологических исследований развил идеи А.Н. Леонтьева. Данная позиция известна как концепция Леонтьева-Фабри.

Выделяется две стадии развития психики:

1. Сенсорная психика. Эта стадия имеет два уровня, низший и высший. Низший уровень представлен одноклеточными организмами; способ организации нервной системы - диффузный (равномерное распределение нервных клеток по всему телу); ведущий тип активности - таксис. Высший 
уровень - многоклеточные организмы; нервная система - гангиозная (узловая, формирование нервных узлов); ведущий тип активности - таксис, простейшие условные рефлексы.

2. Перцептивная психика. Данная стадия включает три уровня. Низший уровень. Нервная система - трубчатая (включает элементы диффузной и ганглиозной системы с дальнейшим усилением развития головного отдела); ведущий тип активности - научение. Высший уровень. Усложнение нервной системы и увеличение головного отдела, появление коры головного мозга; форма активности - научение, элементарное мышление. Наивысший уровень. Происходит развитие коры головного мозга и увеличение лобных долей. Форма активности, научение, мышление, орудийная деятельность.

Становление и развитие психики на уровне сознания (человек) является предметом анализа в рамках культурно-исторической концепции развития психики, изложенной в трудах Л.С. Выготского. Общая логика развития от низших психических функций (врожденных и неконтролируемых) к высшим психическим функциям (приобретенным, социальным и произвольным).

Деятельность психики, высших психических функций протекает в пространстве двух основных механизмов: интериоризация и экстериоризация. Интериоризация представляет собой процесс перехода внешнего действия во внутренний план сознания. По Л.С. Выготскому, происходит замещение реального действия знаком, символом, который интегрируется в структуру сознания субъекта. Экстериоризация - это процесс «разворачивания» знакового содержания сознания во внешние действия.

\section{Рекомендуемая литература для самоподготовки}

Гуревич, П. С. Психология : учебник для вузов / П. С. Гуревич. - 2-е изд., перераб. и доп. - Москва : Издательство Юрайт, 2020. - 465 с. - 
(Высшее образование). - ISBN 978-5-9916-5042-7. - Текст : электронный // ЭБС Юрайт [сайт]. — URL: https://urait.ru/bcode/449915

Лебедев, А. Н. Психология для экономистов : учебник и практикум для вузов / А. Н. Лебедев. - Москва : Издательство Юрайт, 2020. - 328 с. (Высшее образование). — ISBN 978-5-9916-5093-9. — Текст : электронный // ЭБС Юрайт [сайт]. — URL: https://urait.ru/bcode/450257

Психология : учебник и практикум для вузов / А. С. Обухов [и др.] ; под общей редакцией А. С. Обухова. - 2-е изд., перераб. и доп. - Москва : Издательство Юрайт, 2020. - 404 c. - (Высшее образование). ISBN 978-5-534-00631-5. — Текст : электронный // ЭБС Юрайт [сайт]. URL: https://urait.ru/bcode/449860

\section{Задания для самостоятельной работы}

1. Приведите примеры психической активности живых организмов, находящихся на различных стадиях психического развития.

2. Составьте таблицу «Формы проявления психики»

\begin{tabular}{|l|l|}
\hline \multicolumn{1}{|c|}{ Проявления психики } & \multicolumn{1}{c|}{ Содержание } \\
\hline Когнитивные процессы & ощущения, ... \\
\hline Мотивационные процессы & $\cdots$ \\
\hline Свойства характера & $\cdots$ \\
\hline$\ldots$ & $\cdots$ \\
\hline
\end{tabular}

3. Нарисуйте схему рефлексии и кратко охарактеризуйте основные этапы. 


\section{МЕТОДЫ ПСИХОЛОГИИ}

Психология, как и другие научные области имеет собственный набор процедур исследования своего предмета. Совокупность всех процедур можно рассматривать в аспекте следующих понятий: методология, метод, методика.

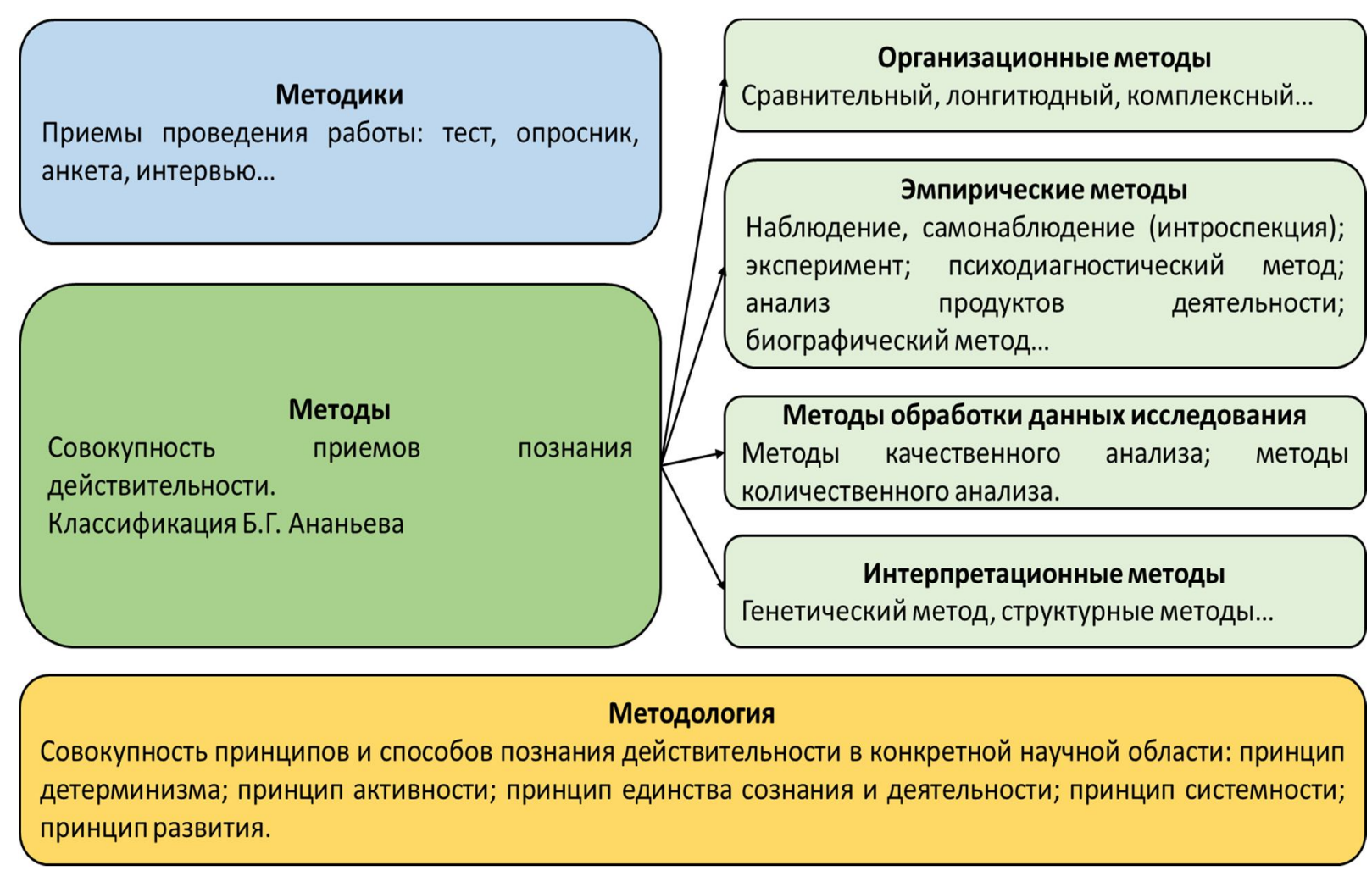

\section{Рисунок 2. Основные понятия: методология, метод, методика}

Методология - это базовый, философско-теоретический уровень познания. Здесь формулируются основные постулаты о проявлениях психики и способах ее исследования.

На уровне метода формируется свод правил и приемов изучения психических явлений.

Методика представляет собой конкретный прием или операцию, направленную на фиксацию конкретного проявления психики. 


\section{Рекомендуемая литература для самоподготовки}

Гуревич, П. С. Психология : учебник для вузов / П. С. Гуревич. - 2-е изд., перераб. и доп. - Москва : Издательство Юрайт, 2020. - 465 с. (Высшее образование). - ISBN 978-5-9916-5042-7. — Текст : электронный // ЭБС Юрайт [сайт]. — URL: https://urait.ru/bcode/449915

Лебедев, А. Н. Психология для экономистов : учебник и практикум для вузов / А. Н. Лебедев. - Москва : Издательство Юрайт, 2020. - 328 с. (Высшее образование). - ISBN 978-5-9916-5093-9. - Текст : электронный // ЭБС Юрайт [сайт]. — URL: https://urait.ru/bcode/450257

Психология : учебник и практикум для вузов / А. С. Обухов [и др.] ; под общей редакцией А. С. Обухова. - 2-е изд., перераб. и доп. - Москва : Издательство Юрайт, 2020. - 404 c. - (Высшее образование). ISBN 978-5-534-00631-5. - Текст : электронный // ЭБС Юрайт [сайт]. URL: https://urait.ru/bcode/449860

\section{Задания для самостоятельной работы}

1. В истории психологии имеется ряд исследований, которые вызвали активный общественный резонанс. Приведите примеры таких «неэтичных» исследований, поясните, что именно является нарушением этических норм.

2. Посмотрите документальный фильм «Я и другие». Приведите примеры, как данные психологические явления проявляются в сфере вашей будущей профессиональной деятельности.

3. Обоснуйте значимость использования статистических методов в психологических исследованиях, приведите примеры. 


\section{СОЗНАНИЕ}

Сознание - идеальная форма отражения, воспроизведения, порождения действительности, что не мешает ей быть реальной, объективной, бытийной, т. е. участной в бытии. Сознание - это высшая, свойственная только человеку и связанная с речью функция мозга, заключающаяся в обобщенном, оценочном и целенаправленном отражении и конструктивно-творческом преобразовании действительности, в предварительном мысленном построении действий и предвидении их результатов, в разумном регулировании поведения человека [1].

Основные характеристики сознания:

- Активность, направленность на предмет; сознание - это всегда сознание чего-либо, например, в настоящий момент, мое сознание направлено на написание данного текста, а у вас, в свою очередь, на прочтение этого текста.

- Способность к рефлексии и самонаблюдению - осознание самого сознания, например, напечатав данный текст, я могу описать как я это сделал, охарактеризовав способ и процедуру данного действия.

- Мотивационно-ценностный характер сознания. Мотивационно-ценностный аспект связан с формированием самосознания и последующим восприятием, и реагированием на события исходя из тех ценностей, которые присвоил субъект.

- Различная степень (уровни) ясности осознания. В различные моменты жизнедеятельности мы проявляем различный уровень ясности осознания действительности. Можно установить континуум от состояния комы (выключенное сознание с полной утратой восприятия окружающего мира) до состояния творческого озарения (предельной ясности осознания). 


\section{Функции сознания}

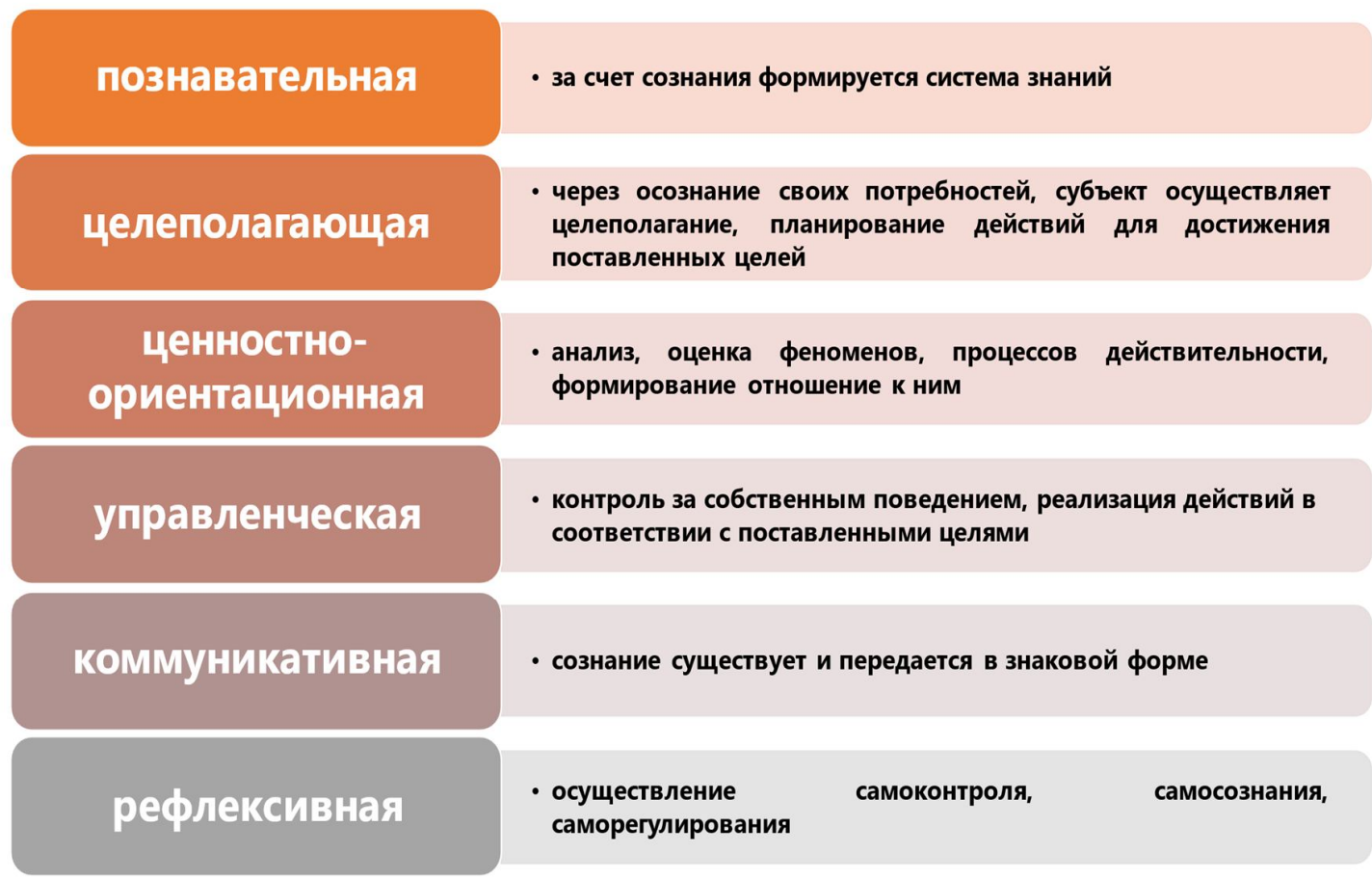

Рисунок 3. Основные функции сознания

\section{Неосознаваемые психические процессы}

Бессознательное - это форма психического отражения, в которой образ действительности и отношение к ней человеком не рефлексируется, m.e. не осознается. Бессознательное (англ. unconscious) - понятие, обозначающее совокупность психических образований, процессов и механизмов, в функционировании и влиянии которых субъект не отдает себе отчета [1]. 


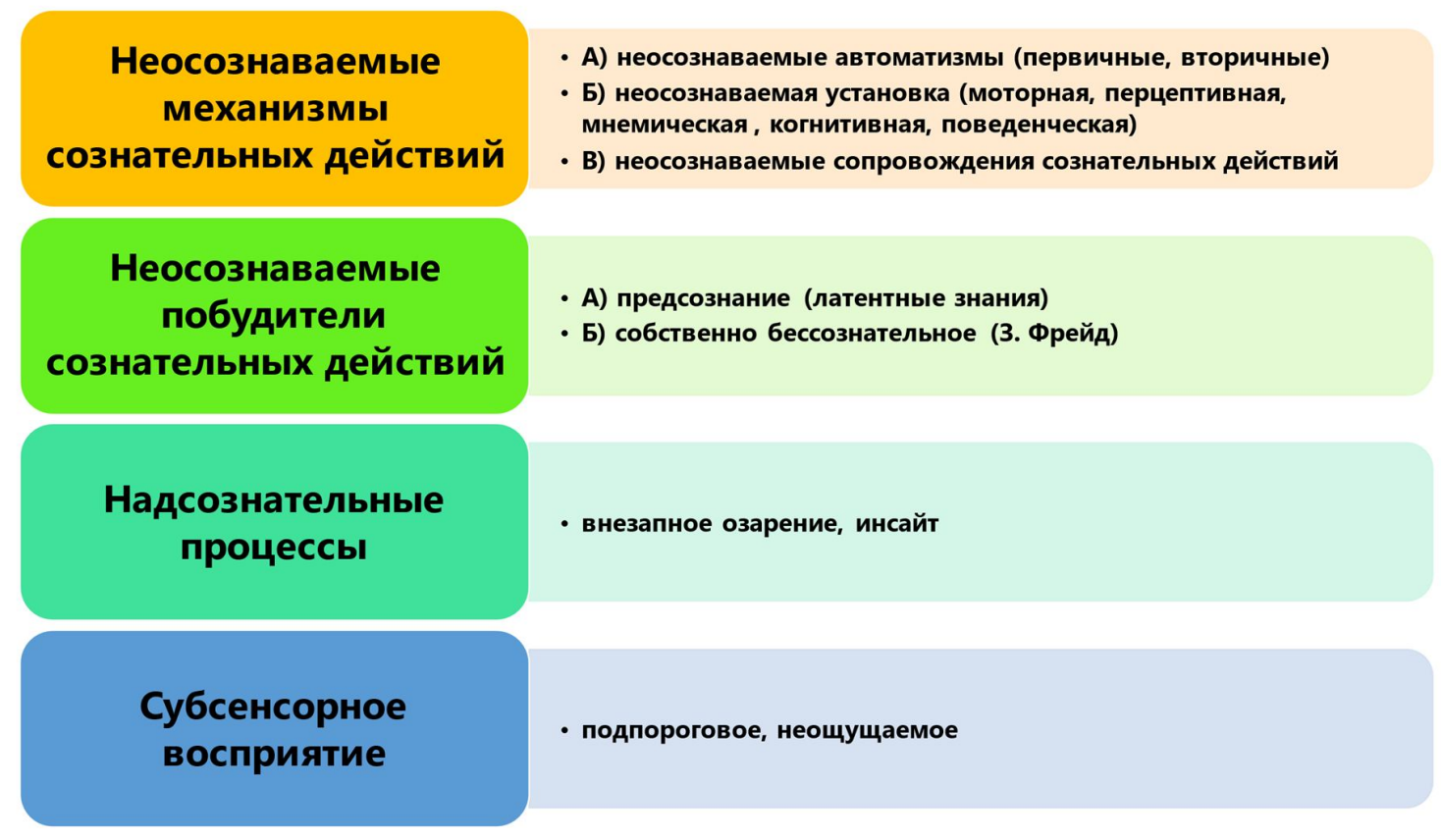

\section{Рисунок 4. Неосознаваемые психические процессы [2]}

\section{Рекомендуемая литература для самоподготовки}

Гуревич, П. С. Психология : учебник для вузов / П. С. Гуревич. - 2-е изд., перераб. и доп. - Москва : Издательство Юрайт, 2020. - 465 с. (Высшее образование). — ISBN 978-5-9916-5042-7. — Текст : электронный // ЭБС Юрайт [сайт]. — URL: https://urait.ru/bcode/449915

Лебедев, А. Н. Психология для экономистов : учебник и практикум для вузов / А. Н. Лебедев. - Москва : Издательство Юрайт, 2020. - 328 с. (Высшее образование). — ISBN 978-5-9916-5093-9. — Текст : электронный // ЭБС Юрайт [сайт]. — URL: https://urait.ru/bcode/450257

Психология : учебник и практикум для вузов / А. С. Обухов [и др.] ; под общей редакцией А. С. Обухова. - 2-е изд., перераб. и доп. - Москва : Издательство Юрайт, 2020. - 404 c. - (Высшее образование). - 
ISBN 978-5-534-00631-5. — Текст : электронный // ЭБС Юрайт [сайт]. URL: https://urait.ru/bcode/449860

\section{Задания для самостоятельной работы}

1. Заполните таблицу, раскройте характеристики сознания.

\begin{tabular}{|l|l|}
\hline \multicolumn{2}{|c|}{ Психологические характеристики сознания } \\
\hline Ощущение себя познающим субъектом. & $\ldots$ \\
\hline $\begin{array}{l}\text { Мысленное представление и воображение } \\
\text { действительности. }\end{array}$ & \\
\hline Цель и воля. & \\
\hline Рефлексивная способность. & \\
\hline Способность к коммуникации. & \\
\hline $\begin{array}{l}\text { Сознание - это совокупность знаний, объективных } \\
\text { законов, свойств и возможностей мира, в котором } \\
\text { мы живем. }\end{array}$ & \\
\hline $\begin{array}{l}\text { В сознании отражаются не все и не случайные, а } \\
\text { только главные, существенные характеристики } \\
\text { предметов, событий и явлений. }\end{array}$ & \\
\hline Наличие интеллектуальных схем. & \\
\hline
\end{tabular}

2. Несоответствие социальных установок (оценок) и реального поведения отражено в парадоксе Р. Лапьера. Ознакомьтесь с данной информацией и приведите примеры проявления данного парадокса в современном мире.

3. Дайте характеристику бессознательных проявлений, исследованных 3. Фрейдом. 


\section{ПОВЕДЕНИЕ И ДЕЯТЕЛЬНОСТЬ ЧЕЛОВЕКА}

Характеристикой, которая объединяет живые существа является активность. Активность обеспечивает взаимосвязь живого организма с окружающей действительностью. Сама активность порождается потребностями, актуальной необходимостью в чем-то. Общую логику формирования активности можно представить так, как это отображено на рисунке 5.

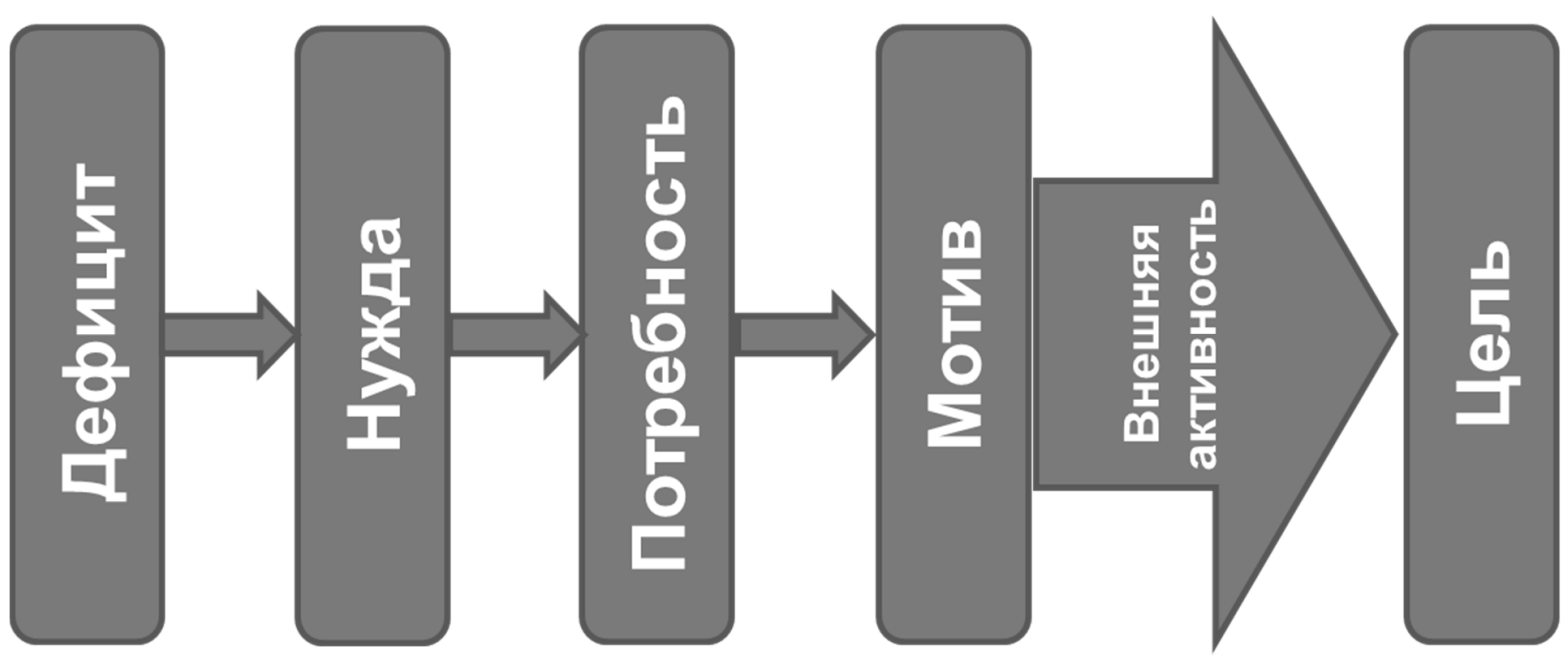

Рисунок 5. Общая схема активности

Состояние дефицита - это наиболее глубокий (физиологический) уровень. Состояние дефицита можно интерпретировать как буквальную недостаточность химических веществ в организме, например глюкозы в крови [6].

Нужда - это состояние, которое в психологии имеет массу трактовок. Мы подразумеваем под состоянием нужды такое состояние, в котором субъект не имеет четкого представления о предмете, который мог бы удовлетворить его. По меткому выражению М.Е. Салтыкова-Щедрина «Чего-то хотелось: не 
то конституции, не то севрюжины с хреном, не то взять бы да ободрать кого-нибудь» [8, стр. 580].

Потребность, мы понимаем как момент встречи субъекта с предметом могущим удовлетворить его потребность.

Мотив - по определению Е.П. Ильина, сложное, интегральное психологическое образование.

Названные выше компоненты составляют внутреннюю часть активности. Внешняя активность проявляется в виде совокупности действий, движений, которые приводят к достижению имеющейся цели, возникшей на этапе формирования мотива.

Различие в понятиях поведение и деятельность, можно трактовать разными способами. Первый вариант - деятельность - это система включающая в себя совокупность внутренних и внешних проявлений; свойственно только человеку; опирается на осознанные цели и мотивы. Поведение, в данном контексте рассматривается как внешняя, наблюдаемая активность. То есть поведение - это наблюдаемая часть деятельности. Второй вариант позволяет дифференцировать понятия в более широком смысле. Поведение - это активность живых существ (животных), связанная с удовлетворением потребностей без сколько-нибудь значительного преобразования действительности. Тогда как деятельность - это всегда преобразование действительности.

\section{Формы поведения:}

Инстинкт (врожденная форма);

Научение (приобретенная форма);

Интеллектуальные формы поведения животных. Это высший тип поведения животных. 
Таблица 4. Формы научения

\begin{tabular}{|l|l|}
\hline \multicolumn{1}{|c|}{ Категория } & \multicolumn{1}{|c|}{ Основные формы } \\
\hline \multirow{2}{*}{$\begin{array}{l}\text { Неассоциативное обучение (простые } \\
\text { формы) }\end{array}$} & Привыкание \\
\cline { 2 - 2 } $\begin{array}{l}\text { Особые формы неассциативного } \\
\text { обучения, тесно связанные с } \\
\text { инстинтом и/или разумом }\end{array}$ & Запечатление (импринтинг) \\
\cline { 2 - 2 } Ассоциативное обучение & Подражание \\
\hline \multirow{2}{*}{ Когнитивное обучение } & Условный рефлекс \\
& $\begin{array}{l}\text { Латентное обучение, когнитивные карты } \\
\text { Сенсорное (перцептивное) обучение } \\
\text { Инсайт } \\
\text { Элементарное мышление }\end{array}$ \\
\hline
\end{tabular}

\section{Структура деятельности}

Структура деятельности может быть представлена как совокупность уровней деятельности и отдельных структурных элементов (рисунок 6).

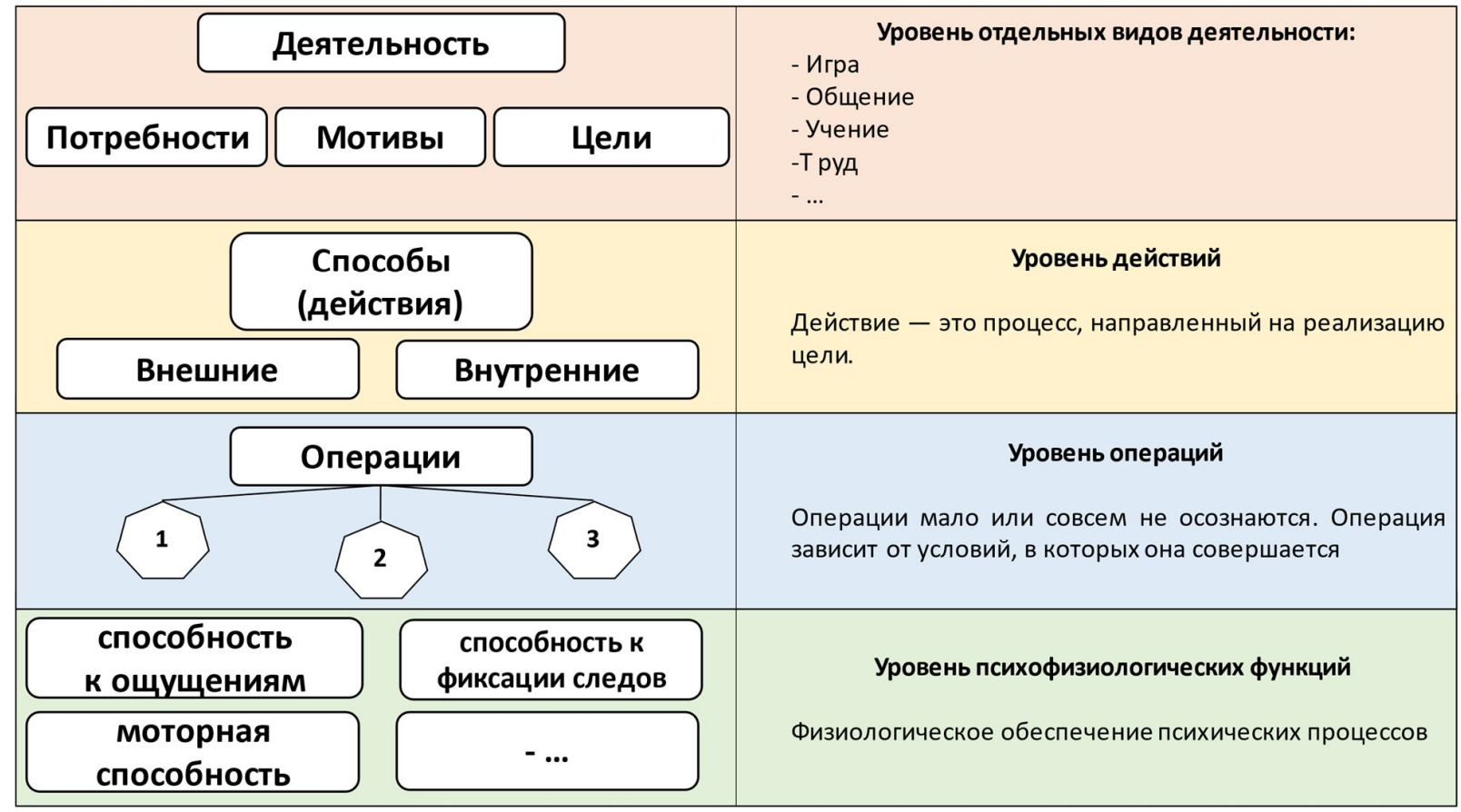

Рисунок 6. Структура деятельности 


\section{Рекомендуемая литература для самоподготовки}

Гуревич, П. С. Психология : учебник для вузов / П. С. Гуревич. - 2-е изд., перераб. и доп. - Москва : Издательство Юрайт, 2020. - 465 с. (Высшее образование). - ISBN 978-5-9916-5042-7. - Текст : электронный // ЭБС Юрайт [сайт]. — URL: https://urait.ru/bcode/449915

Лебедев, А. Н. Психология для экономистов : учебник и практикум для вузов / А. Н. Лебедев. - Москва : Издательство Юрайт, 2020. - 328 с. (Высшее образование). - ISBN 978-5-9916-5093-9. — Текст : электронный // ЭБС Юрайт [сайт]. — URL: https://urait.ru/bcode/450257

Психология : учебник и практикум для вузов / А. С. Обухов [и др.] ; под общей редакцией А. С. Обухова. - 2-е изд., перераб. и доп. - Москва : Издательство Юрайт, 2020. - 404 c. - (Высшее образование). ISBN 978-5-534-00631-5. - Текст : электронный // ЭБС Юрайт [сайт]. URL: https://urait.ru/bcode/449860

\section{Задания для самостоятельной работы}

1. Раскройте психологические черты деятельности.

2. В соответствие с приведенной в теоретическом материале схемой деятельности, опишите свою деятельность (трудовую, учебную).

3. Приведите примеры внешних и внутренних побудителей деятельности. 


\section{МОТИВАЦИОННАЯ СФЕРА}

Мотив (англ. incentive) - 1) материальный или идеальный «предмет», который побуждает и направляет на себя деятельность или поступок, смысл которых состоит в том, что с помощью М. удовлетворяются определенные потребности субъекта; 2) психический образ данного предмета [1].

Мотивация - это процесс формирования мотива [6].

Теоретические подходы к изучению проблемы мотивации можно представить следующим образом (рисунок 7).

\begin{tabular}{|l|l|}
\hline Концептуальные теории мотивации & $\begin{array}{l}\text {-психоаналитическая теория 3. Фрейда, } \\
\text {-теория «драйвов» К. Халла, } \\
\text {-гедоническая теория К.Г. Юнга, } \\
\text {-теория условных рефлексов И.П. Павлова. }\end{array}$ \\
\hline Содержательные теории мотивации & $\begin{array}{l}\text { - теория иерархии потребностей по А.Г. Маслоу, } \\
\text { - теории «Х» «Ү» Д. Мак-Грегора, } \\
\text { - теория «мотивационной гигиены» } \\
\text { Ф.Герцберга, } \\
\text { - Теория К. Альдерфера, } \\
\text { - Теория потребностей Д. Мак-Клеланда. }\end{array}$ \\
\hline Процессуальные теории мотивации & $\begin{array}{l}\text {-теория ожиданий В. Врума, } \\
\text {-теория справедливости С. Адамса, } \\
\text {-модель Л. Портера- Э. Лоулера, } \\
\text {-теория аттрибуции Ф. Хайдера, } \\
\text {-метод регулирования организационного } \\
\text { поведения Б. Скиннера, } \\
\text {-теория цели Э. Лока. }\end{array}$ \\
\hline
\end{tabular}

\section{Рисунок 7. Теории мотивации}

\section{Рекомендуемая литература для самоподготовки}

Гуревич, П. С. Психология : учебник для вузов / П. С. Гуревич. - 2-е изд., перераб. и доп. - Москва : Издательство Юрайт, 2020. - 465 с. (Высшее образование). - ISBN 978-5-9916-5042-7. — Текст : электронный // ЭБС Юрайт [сайт]. — URL: https://urait.ru/bcode/449915 
Лебедев, А. Н. Психология для экономистов : учебник и практикум для вузов / А. Н. Лебедев. - Москва : Издательство Юрайт, 2020. - 328 с. (Высшее образование). — ISBN 978-5-9916-5093-9. — Текст : электронный // ЭБС Юрайт [сайт]. — URL: https://urait.ru/bcode/450257

Психология : учебник и практикум для вузов / А. С. Обухов [и др.] ; под общей редакцией А. С. Обухова. - 2-е изд., перераб. и доп. - Москва : Издательство Юрайт, 2020. - 404 с. - (Высшее образование). ISBN 978-5-534-00631-5. - Текст : электронный // ЭБС Юрайт [сайт]. URL: https://urait.ru/bcode/449860

\section{Задания для самостоятельной работы}

1. Укажите основные мотивы трудовой деятельности (приведите примеры).

2. Укажите основные мотивы девиантного поведения (приведите примеры).

3. Рассмотрите подробнее схему структуры мотива (по Е.П. Ильину), приведите примеры для каждого компонента.

4. Изучите и сравните основные подходы к проблеме мотивации (по схеме из теоретической части). Результаты сравнения оформите в виде таблицы.

\begin{tabular}{|c|c|c|c|}
\hline \multirow{2}{*}{ Теория } & $\begin{array}{c}\text { Основные } \\
\text { побудители }\end{array}$ & $\begin{array}{c}\text { Структура мотива / } \\
\text { мотивации / } \\
\text { мотивационной сферы }\end{array}$ & Пример \\
\hline Теория З. Фрейда & & & \\
\hline$\ldots$ & & & \\
\hline
\end{tabular}




\section{ЭМОЦИОНАЛЬНО-ВОЛЕВАЯ СФЕРА}

Эмоции (от лат. emovere - волновать, возбуждать) - особый класс психических процессов и состояний (человека и животных), связанных с инстинктами, потребностями, мотивами и отражающих в форме непосредственного переживания (удовлетворения, радости, страха и т. д.) значимость действующих на индивида явлений и ситуаций для осуществления его жизнедеятельности. Сопровождая практически любые проявления активности субъекта, Э. служат одним из главных механизмов внутренней регуляции психической деятельности и поведения, направленных на удовлетворение актуальных потребностей [1].

Эмоции - особый класс субъективных психических состояний, отражающих в форме непосредственных переживаний ощущений приятного или неприятного, отношения человека к миру, людям, процессам и результатом практической деятельности.

К эмоциональной сфере личности относят настроения, чувства, аффекты, страсти, стрессы и др. Эти эмоции включены во все психические процессы и состояния человека. Любые проявления активности человека сопровождается эмоциональными переживаниями. Факты доказывают: 1) врожденный характер основных эмоций и их изображение на лице; 2) наличие генотипически обусловленной способности к их пониманию у живых существ.

Функции эмоций:

1. Сигнальная. Функция общения, т.е. сообщения человеку информации о состоянии говорящего и его отношении к тому, что в данный момент происходит.

2. Стимулирующая. Функция воздействия, т.е. оказания определенного влияния на того, кто является субъектом восприятия эмоционально-выразительных движений. 
3. Оценочная функция.

4. Экспрессивная функция.

5. Коммуникативная функция. Здесь эмоции могут служить языком.

6. Регулятивная. Функция оценки хода и результатов деятельности.

7. Защитная. Функция приспособления к окружающим условиям.

8. Мотивационная функция. Желание испытать какую-либо эмоцию может стать мотивом для совершения каких-либо действий.

T.o. эмоциональные явления биологически, в процессе эволюции закрепились как своеобразный способ поддержания жизненного процесса.

Эмоции и чувства обладают самостоятельной ценностью для личности. Виды эмоций.

I. Можно классифицировать: 1) по интенсивности; 2) по продолжительности; 3) осознанности; 4) происхождению; 5) условиям возникновения; 6) воздействию на организм; 7) динамике развития; 8) направленности (на себя, на других, на мир, на прошлое, настоящее или будущее); 10) по способу их выражения во внешнем проявлении (экспрессии); 11) по нейрофизиологической основе, 12) «знаку» (положительные, отрицательные, нейтральные); 13) по их влиянию на деятельность человека (тормозят или активизируют и т.д.).

II. К. Изард выделил ряд основных эмоциональных состояний, которые назвал фундаментальными, а все остальные производными. Каждая из фундаментальных имеет свой спектр характеристик и внешних проявлений: 1) интерес-волнение; 2) радость; 3) удивление; 4) страдание - горе, 5) гнев; 6) отвращение; 7) презрение; 8) страх; 9) стыд [5].

III. Б.И. Додонов перечислил социальные эмоции, поскольку они приобретаются прижизненно в результате взаимодействия с людьми: 1) альтруистические эмоции, которые возникают на основе потребности в 
содействии, помощи, покровительстве другим людям; 2) коммуникативные эмоции возникают на основе потребности в общении; 3) глорические эмоции связаны с потребностью в самоутверждении, в славе; 4) праксические эмоции вызываются той деятельностью, которой занят человек, ее успешностью или неуспешностью; 5) пугнические эмоции (от лат. - борьба), в основе которых лежит потребность в преодолении опасности, интерес к борьбе; 6) романтические эмоции, в основе которых лежит стремление ко всему необычному; 7) гностические эмоции связаны с познавательной деятельностью личности (это интеллектуальные эмоции); 8) эстетические эмоции, которые возникают под влиянием произведений искусства, созерцания природы; 9) гедонистические эмоции, связанны с удовлетворением потребности в телесном и душевном комфорте; 10) акизитивные эмоции связаны с интересом к накоплению, коллекционированию вещей, выходящему за пределы практической нужды в них [3].

IV. По влиянию на деятельность человека эмоции делят на стенические и астенические. Стенические эмоции отличаются действенностью, они становятся побуждениями к поступкам, к высказываниям, увеличивают напряжение сил. Переживая сочувствие к другу, человек ищет способ помочь ему. При стенических эмоциях человеку трудно молчать, трудно не действовать активно. Астенические эмоции характеризуются пассивностью или созерцательностью, переживание чувств расслабляет человека. Иногда переживая сильное чувство, человек уходит в себя, замыкается.

Информационная теория П.В. Симонова:

$$
Э=\Pi \text { Э (Ин - Ис), где: }
$$

Э - эмоция;

П - сила и качество актуальной потребности; 
Ин - информация о средствах, времени и ресурсах, теоретически необходимых для удовлетворения потребности;

Ис - информация о средствах, времени и ресурсах, которые в данный момент есть у человека в распоряжении [9].

Воля (англ. volition, will) - способность человека действовать в направлении сознательно поставленной цели, преодолевая при этом внутренние препятствия (т. е. свои непосредственные желания и стремления). В традиционной психологии В. либо рассматривалась как самодовлеющий источник человеческой активности, обусловливающий независимость поведения от объективных причин, либо отрицалась вовсе путем сведения ее к др. психическим процессам. В сов. психологии утверждалась объективная детерминированность волевых действий, подчиненность волевых (как и всех др.) процессов собственным специфическим закономерностям [1].

Общее представление о структуре волевого акта можно представить на схеме.

\begin{tabular}{|c|c|c|}
\hline $\begin{array}{l}\text { 1. Осознание проблемы } \\
\text { 2. Возникновение влечения, } \\
\text { желания, потребности } \\
\text { 3. На их основе идет постановка цели }\end{array}$ & $\begin{array}{l}\text { 4. Борьба мотивов } \\
\text { 5. Принятие решения }\end{array}$ & $\begin{array}{l}\text { 6. Длительное намерение } \\
\text { 7. Исполнение - переход решения в } \\
\text { действие }\end{array}$ \\
\hline
\end{tabular}

Рисунок 8. Структура волевого акта

\section{Рекомендуемая литература для самоподготовки}

Гуревич, П. С. Психология : учебник для вузов / П. С. Гуревич. - 2-е изд., перераб. и доп. - Москва : Издательство Юрайт, 2020. - 465 с. (Высшее образование). — ISBN 978-5-9916-5042-7. — Текст : электронный // ЭБС Юрайт [сайт]. — URL: https://urait.ru/bcode/449915

Лебедев, А. Н. Психология для экономистов : учебник и практикум для вузов / А. Н. Лебедев. - Москва : Издательство Юрайт, 2020. - 328 с. - 
(Высшее образование). - ISBN 978-5-9916-5093-9. - Текст : электронный // ЭБС Юрайт [сайт]. — URL: https://urait.ru/bcode/450257

Психология : учебник и практикум для вузов / А. С. Обухов [и др.] ; под общей редакцией А. С. Обухова. - 2-е изд., перераб. и доп. - Москва : Издательство Юрайт, 2020. - 404 c. - (Высшее образование). ISBN 978-5-534-00631-5. - Текст : электронный // ЭБС Юрайт [сайт]. URL: https://urait.ru/bcode/449860

\section{Задания для самостоятельной работы}

1. Назовите основные факторы возникновения стресса (приведите примеры).

2. С целью развития навыка осознания собственных эмоций, в течении недели оценивайте происходящие в вашей жизни события и заносите результаты наблюдения в таблицу. Проанализируйте собранные результаты.

\begin{tabular}{|c|c|c|c|}
\hline \multirow{2}{*}{ Факт (ситуация, человек) } & $\begin{array}{c}\text { Мысли, } \\
\text { которые } \\
\text { возникли }\end{array}$ & $\begin{array}{c}\text { Физические } \\
\text { ощущения }\end{array}$ & Эмоции \\
\hline & & & \\
\hline
\end{tabular}

3. Рассмотрите такое понятие как «прокрастинация», выделите основные факторы, которые приводят к ее появлению (приведите примеры). 


\section{ПОЗНАВАТЕЛЬНЫЕ ПРОЦЕССЫ}

В первом приближении, познавательные процессы можно упорядочить следующим образом.

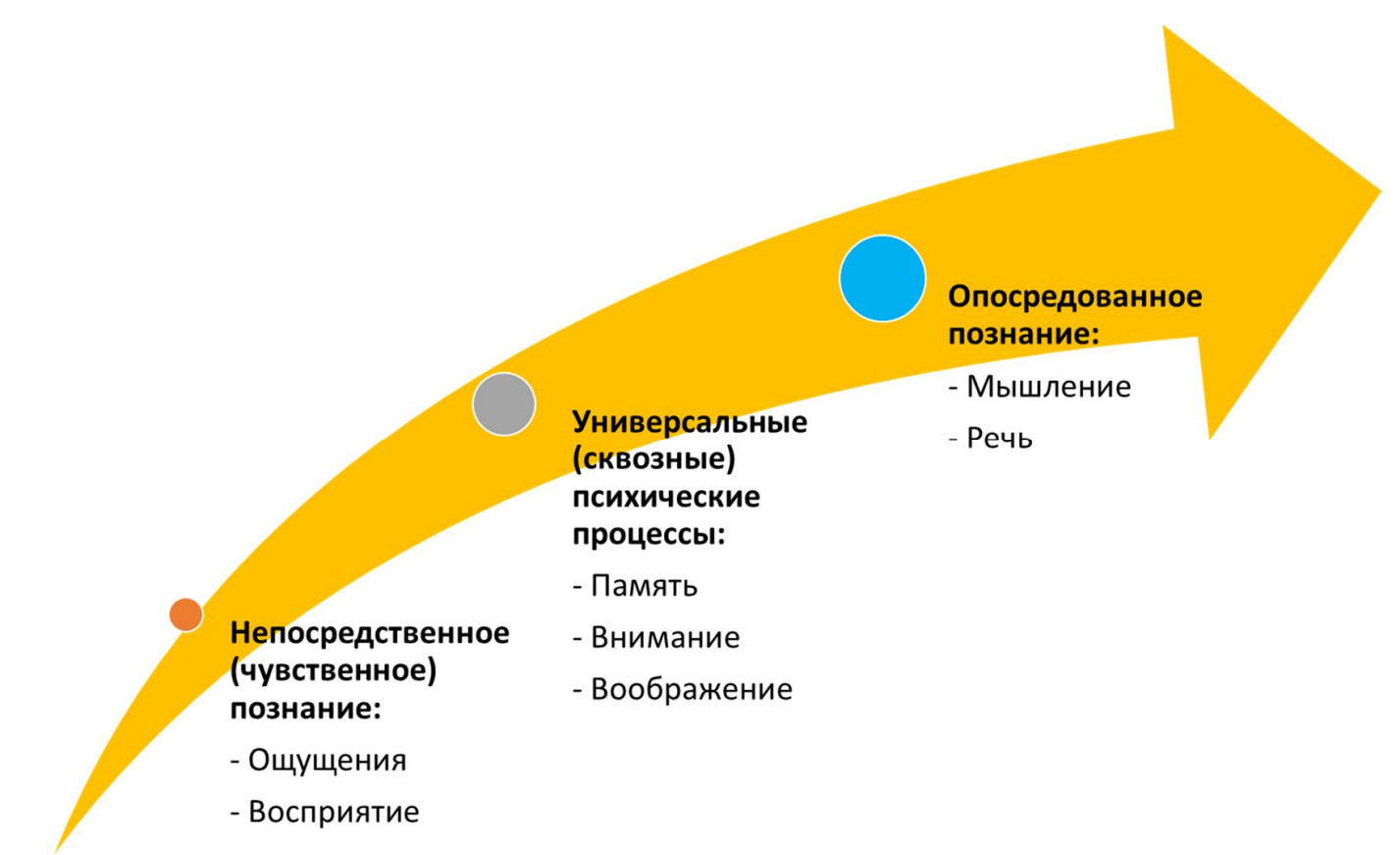

\section{Рисунок 9. Систематизация познавательных процессов}

Приведем определения познавательных процессов [1].

Ощущение (англ. sensation) - 1) психофизический процесс непосредственно чувственного отражения (познания) отдельных свойств явлений и предметов объективного мира, т. е. процесс отражения прямого воздействия стимулов на органы чувств, раздражения последних (см. Анализатор), а также 2) возникающее в результате указанного процесса субъективное (психическое) переживание силы, качества, локализации и др. характеристик воздействия на органы чувств (рецепторы).

Восприятие (англ. perception). 
1. Субъективный образ предмета, явления или процесса, непосредственно воздействующего на анализатор или систему анализаторов (употребляются также термины «образ восприятия», «перцептивный образ»).

2. Сложный психофизиологический процесс формирования перцептивного образа (употребляются также термины «перцепция», «перцептивный процесс»). Иногда термином В. обозначается система действий, направленных на ознакомление с предметом, воздействующим на органы чувств, т. е. чувственно-исследовательская деятельность наблюдения.

Память (англ. memory) — запоминание, сохранение и последующее воспроизведение индивидом его опыта. Физиологической основой П. является образование, сохранение и актуализация временных связей в мозге (см. Мнема, Памяти физиологические механизмы, Следы памяти, Энграмма). Временные связи и их системы образуются при смежном во времени действии раздражителей на органы чувств и при наличии у индивида ориентировки, внимания, интереса к этим раздражителям.

Внимание (англ. attention) — процесс и состояние настройки субъекта на восприятие приоритетной информации и выполнение поставленных задач. Теоретически и операционально В. (настройка) характеризуется уровнем (интенсивностью, концентрацией), объемом (широтой, распределением), селективностью, скоростью переключения (перемещения), длительностью и устойчивостью.

Воображение (фантазия) (англ. imagination) - универсальная человеческая способность к построению новых целостных образов действительности путем переработки содержания сложившегося практического, чувственного, интеллектуального и эмоционально-смыслового опыта. В. - это способ овладения человеком сферой возможного будущего, придающий его деятельности целеполагающий и проектный характер, 
благодаря чему он выделился из «царства» животных. Будучи психологической основой творчества, В. обеспечивает как историческое создание форм культуры, так и их освоение в онтогенезе.

Мышление (англ. thinking) — психический процесс отражения действительности, высшая форма творческой активности человека. М. постольку процесс отражения объектов, поскольку оно есть творческое преобразование их субъективных образов в сознании человека, их значения и смысла для разрешения реальных противоречий в обстоятельствах жизнедеятельности людей, для образования ее новых целей, открытия новых средств и планов их достижения, раскрывающих сущность объективных сил природы и общества.

Речь (англ. speech) — исторически сложившаяся форма общения людей посредством языка. Речевое общение осуществляется по законам данного языка (рус., англ. и т. п.), который представляет собой систему фонетических, лексических, грамматических и стилистических средств и правил общения. Р. и язык составляют сложное диалектическое единство. Р. осуществляется по правилам языка, и вместе с тем под действием ряда факторов (требований общественной практики, развития науки, взаимных влияний языков и др.) она изменяет и совершенствует язык.

Высшее абстрактно-понятийное мышление невозможно без Р. (см. Мышление дискурсивное). Речевая деятельность имеет существенное значение для развития и др. форм мышления (наглядно-действенного и наглядно-образного). Р. тесно связана и со всеми др. психическими функциями-процессами. Включаясь в процесс восприятия, она делает его более обобщенным и дифференцированным; вербализация запоминаемого материала способствует осмысленности запоминания и воспроизведения; 
существенная роль Р. в воображении, при осознании своих эмоций, при регулировании своего поведения и т. д.

\section{Рекомендуемая литература для самоподготовки}

Гуревич, П. С. Психология : учебник для вузов / П. С. Гуревич. - 2-е изд., перераб. и доп. - Москва : Издательство Юрайт, 2020. - 465 с. (Высшее образование). — ISBN 978-5-9916-5042-7. — Текст : электронный // ЭБС Юрайт [сайт]. — URL: https://urait.ru/bcode/449915

Лебедев, А. Н. Психология для экономистов : учебник и практикум для вузов / А. Н. Лебедев. - Москва : Издательство Юрайт, 2020. - 328 с. (Высшее образование). - ISBN 978-5-9916-5093-9. - Текст : электронный // ЭБС Юрайт [сайт]. — URL: https://urait.ru/bcode/450257

Психология : учебник и практикум для вузов / А. С. Обухов [и др.] ; под общей редакцией А. С. Обухова. - 2-е изд., перераб. и доп. - Москва : Издательство Юрайт, 2020. - 404 с. - (Высшее образование). ISBN 978-5-534-00631-5. - Текст : электронный // ЭБС Юрайт [сайт]. URL: https://urait.ru/bcode/449860

\section{Задания для самостоятельной работы}

1. Заполните таблицу, указав основные характеристики и свойства познавательных процессов.

\begin{tabular}{|l|c|c|}
\hline \multicolumn{1}{|c|}{ Процесс } & $\begin{array}{c}\text { Классификация / виды } \\
\text { процесса }\end{array}$ & $\begin{array}{c}\text { Свойства / } \\
\text { характеристики }\end{array}$ \\
\hline Ощущения & & \\
\hline Восприятие & & \\
\hline Память & & \\
\hline Внимание & & \\
\hline Воображение & & \\
\hline Мышление & & \\
\hline Речь & & \\
\hline
\end{tabular}




\section{ПРОБЛЕМА ЛИЧНОСТИ В ПСИХОЛОГИИ}

В психологической литературе, мы можем обнаружить достаточное количество представлений относительно феномена личности. Энциклопедическое определение личности, гласит: Личность (англ. personality; от лат. persona - маска актера; роль, положение; лицо, личность). В общественных науках Л. рассматривается как особое качество человека, приобретаемое им в социокультурной среде в процессе совместной деятельности и общения. В гуманистических философских и психологических концепциях Л. - это человек как ценность, ради которой осуществляется развитие общества (см. И. Кант). При всем многообразии подходов к пониманию Л. традиционно выделяются след. аспекты этой проблемы: 1) многогранность феноменологии Л., отражающая объективно существующее многообразие проявлений человека в эволюции природы, истории общества и его собственной жизни; 2) междисциплинарный статус проблемы Л., находящейся в сфере изучения общественных и естественных наук; 3) зависимость понимания Л. от образа человека, явно или скрыто существующего в культуре и науке на определенном этапе их развития; 4) несовпадение проявлений индивида, Л. и индивидуальности, исследуемых в рамках относительно независимых друг от друга биогенетического, социогенетического и персоногенетического направлений современного человекознания; 5) разведение исследовательской установки, ориентирующей специалиста на понимание развития Л. в природе и обществе, и практической установки, направленной на формирование или коррекцию Л. в соответствии с целями, заданными обществом или поставленными обратившимся к специалисту конкретным человеком [1]. 
Многогранность понятия личность связана с различными аспектами понимания данного явления. Ниже, на схеме приведены основные фокусы рассмотрения данного понятия.

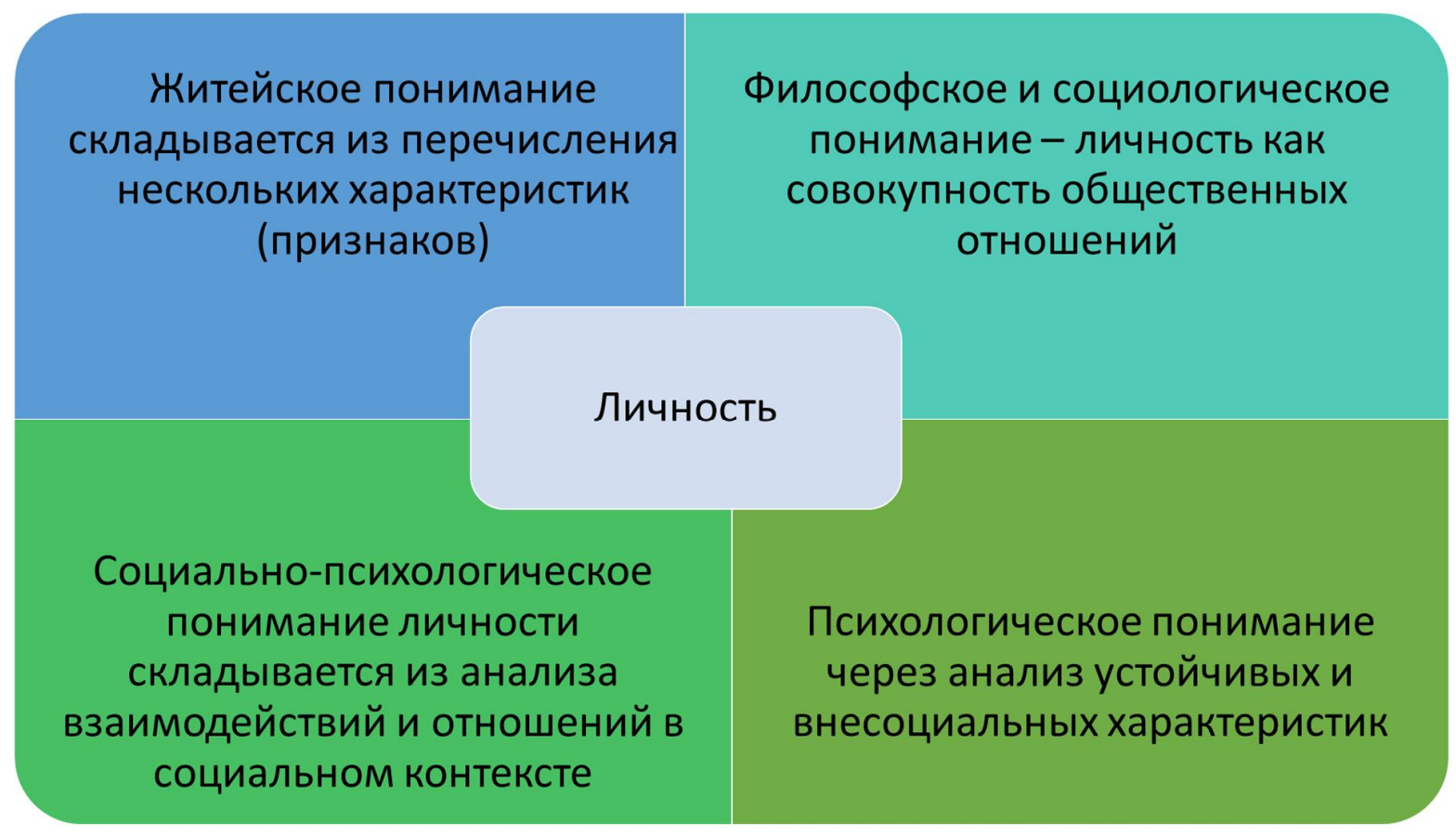

\section{Рисунок 10. Подходы к пониманию личности}

Равно как и определений, можно выделить множество моделей структур личности. Мы рассмотрим структуру, описанную К.К. Платоновым. Все представленные компоненты структуры можно анализировать с позиций фактора оказывающего наибольшее влияние на становление данного компонента. Биопсихические свойства в наибольшей степени зависят от врожденных, психофизиологических особенностей, которые могут варьироваться в небольшой степени в контексте деятельности.

Психические свойства личности в достаточной степени определяются врожденными особенностями, но при этом на их проявление и развитие оказывает социальная среда и факт упражнения в их применении. 


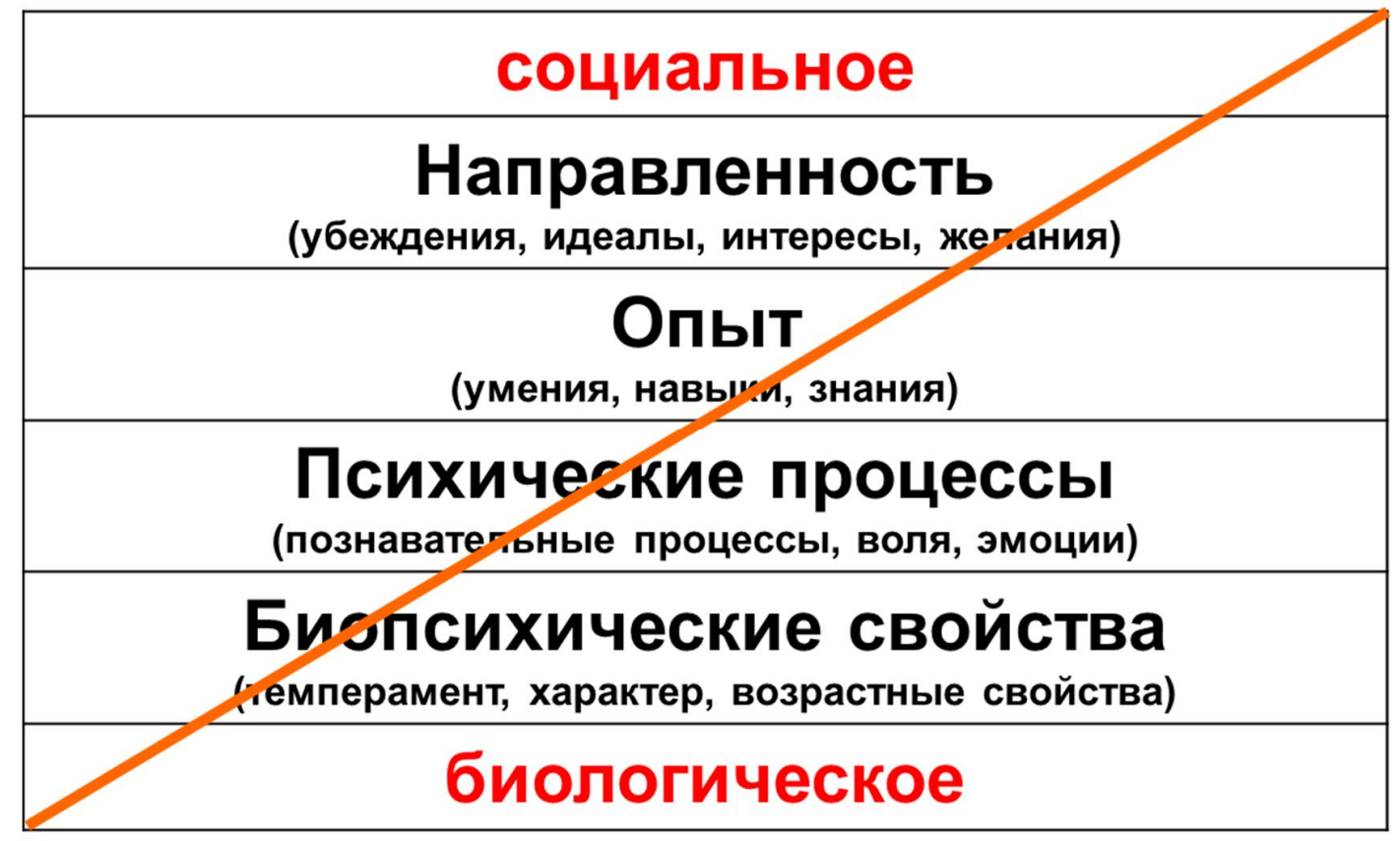

Рисунок 11. Структура личности (К.К. Платонов)

Подструктура личности «опыт» базируясь на биологически обусловленных особенностях в значительной степени зависит от условий деятельности, формируются и развиваются в деятельности.

Направленность личности - подструктура, которая формируется в контексте социальной среды.

\section{Рекомендуемая литература для самоподготовки}

Гуревич, П. С. Психология : учебник для вузов / П. С. Гуревич. - 2-е изд., перераб. и доп. - Москва : Издательство Юрайт, 2020. - 465 с. (Высшее образование). - ISBN 978-5-9916-5042-7. — Текст : электронный // ЭБС Юрайт [сайт]. — URL: https://urait.ru/bcode/449915

Лебедев, А. Н. Психология для экономистов : учебник и практикум для вузов / А. Н. Лебедев. - Москва : Издательство Юрайт, 2020. - 328 с. - 
(Высшее образование). - ISBN 978-5-9916-5093-9. - Текст : электронный // ЭБС Юрайт [сайт]. — URL: https://urait.ru/bcode/450257

Психология : учебник и практикум для вузов / А. С. Обухов [и др.] ; под общей редакцией А. С. Обухова. - 2-е изд., перераб. и доп. - Москва : Издательство Юрайт, 2020. - 404 c. - (Высшее образование). ISBN 978-5-534-00631-5. - Текст : электронный // ЭБС Юрайт [сайт]. URL: https://urait.ru/bcode/449860

\section{Задания для самостоятельной работы}

1. Ознакомьтесь с информацией о моделях структуры личности различных авторов, результаты изучения отобразите в виде сводной таблицы.

\begin{tabular}{|l|l|l|}
\hline Автор теории & $\begin{array}{l}\text { Ключевое понятие } \\
\text { (определение) }\end{array}$ & $\begin{array}{l}\text { Структура личности } \\
\text { (элементы) }\end{array}$ \\
\hline З. Фрейд & $\cdots$ & $\cdots$ \\
\hline Мясищев В. Н. & $\cdots$ & $\cdots$ \\
\hline К.Г. Юнг & & \\
\hline А. Маслоу & & \\
\hline Г. Олпорт & & \\
\hline Е.Б. Старовойтенко & & \\
\hline
\end{tabular}

2. На примере исторической личности, составьте описание психологического портрета личности.

3. Ознакомьтесь с теорией «7 радикалов» В.В. Пономаренко, проведите наблюдение за кем-либо из своих знакомых, определите личностный тип. 


\section{МАЛЫЕ ГРУППЫ}

Группа (англ. group).

1. Некоторое количество предметов или организмов (индивидов), объединенных на основании их пространственной близости друг другу и/или к.-л. реальных связей между ними. Это понятие применяется и в отношении животных (см. Групповое поведение животных).

2. Г. (социальная) - два или более человека, которые взаимодействуют друг с другом, осознают свою групповую принадлежность и участвуют в совместной деятельности. В зрелых Г. существуют свои традиции и нормы. Группой не является толпа (агрегат) — временное скопление людей, которые не участвуют в совместной деятельности. С т. зр. данного определения, Г. не является большая или малая совокупность людей, которые хотя и осознают свою принадлежность к одной совокупности (общности, социальные категории), но не взаимодействуют друг с другом и не участвуют в совместной деятельности (напр., возрастные, половые, расовые и т. п. общности). Выделяется большое количество типов Г.: напр., малые и большие; первичные и вторичные; формальные и неформальные; Г. сверстников и разновозрастные Г.; ин-Г. и аут-Г.; семейные, учебные, трудовые, психотерапевтические (см. Группа встреч) и т. д.; легальные и нелегальные; референтные (эталонные). По понятным причинам в социальной психологии термин «Г.» используется нередко без определения «социальная» [1].

Мы остановимся на рассмотрении малых социальных групп, как

основной единице социального взаимодействия в различных сферах жизнедеятельности.

Помимо определения группы, важно понимать количественные показатели (нижнюю и верхнюю границу) группы. Нижняя граница минимальная возможная численность два человека, диадная группа. Однако, в 
социальной психологии сложился и альтернативный взгляд на минимальный порог - 3 человека. Этот минимальный объем группы объясняется тем, что в группе из двух человек, возникшие конфликтные ситуации могут не получать конструктивного разрешения. Тогда как в группах из трех человек, всегда есть возможность участия третьего члена группы в качестве «независимой» стороны и помочь в разрешении конфликта. Таким образом, данный критерий функциональный. Верхняя граница группы также может быть определена по функциональному признаку. Сколько человек необходимы для решения групповой задачи, такова и будет численность малой группы.

Виды малых социальных групп:

- лабораторные (участие в исследованиях);

- группа социально-психологического тренинга;

- естественные группы (первичный-вторичные, формальные-неформальные, группы членства-референтные группы...).

Любая группа функционирует посредством определенных механизмов. Данные механизмы - групповые эффекты определяют протекание групповых процессов.

Таблица 5. Групповые эффекты

\begin{tabular}{|c|c|}
\hline Групповой эффект & Характеристика \\
\hline $\begin{array}{l}\text { Эффект } \\
\text { фасилитации-ингибиции }\end{array}$ & $\begin{array}{l}\text { Усиление - замедление деятельности в } \\
\text { присутствии других людей. }\end{array}$ \\
\hline Эффект принадлежности к группе & $\begin{array}{lcc}\text { Субъект отождествляет себя со своей } \\
\text { группой. } & \text { Уровни: } & \text { эмоциональный, } \\
\text { когнитивный, поведенческий. }\end{array}$ \\
\hline Эффект Рингельмана (социальная леность) & $\begin{array}{l}\text { Стремление } \text { субъекта к минимизации } \\
\text { собственных усилий в условиях роста } \\
\text { численности группы и снижения уровня } \\
\text { персонификации задачи. }\end{array}$ \\
\hline Эффект «синергии» & $\begin{array}{l}\text { Сумма коллективных усилий превышает } \\
\text { арифметическую сумму индивидуальных } \\
\text { результатов. }\end{array}$ \\
\hline
\end{tabular}




\begin{tabular}{|l|l|}
\hline Эффект группомыслия & $\begin{array}{l}\text { При принятии решения, группа } \\
\text { руководствуется не поиском лучшего } \\
\text { решения а стремлением сохранить } \\
\text { межличностные отношения, «мир» в } \\
\text { группе. Ориентация на поиск согласия. }\end{array}$ \\
\hline Эффект конформизма & $\begin{array}{l}\text { Влияние социальной группы на мнение, } \\
\text { установки и поведение отдельного } \\
\text { субъекта. «Социльное давление». }\end{array}$ \\
\hline Эффект моды (подражания) & $\begin{array}{l}\text { Интеграция группы за счет выработки } \\
\text { единых образцов поведения, стереотипов, } \\
\text { установок. }\end{array}$ \\
\hline Эффект «ореола» («галоэффект») & $\begin{array}{l}\text { Влияние на содержание знаний, мнений, } \\
\text { оценок личнсти специфической } \\
\text { установки, имеющейся одного человека } \\
\text { по отношению кдругому. }\end{array}$ \\
\hline Эффект группового фаворитизма & $\begin{array}{l}\text { Тенденция благоприятствовать членам } \\
\text { своей группы, в противовес членам других } \\
\text { групп. }\end{array}$ \\
\hline Эффект группового эгоизма & $\begin{array}{l}\text { Группа ориентирована на достижение } \\
\text { групповой цели, в противоположность } \\
\text { индивидуальным целям. }\end{array}$ \\
\hline Эффект «маятника» & $\begin{array}{l}\text { Циклическое чередование стенических и } \\
\text { астенических эмоциональных состояний. }\end{array}$ \\
\hline Эффект «волны» & $\begin{array}{l}\text { Это процесс распространения в группе } \\
\text { различных норм, идей, взглядов. }\end{array}$ \\
\hline
\end{tabular}

Процесс развития группы проходит через следующие стадии:

- Стадия становления - соорганизация членов группы посредством групповой цели, установление первичных «экспрессивных» отношений;

- Стадия конфликта - члены группы понимают, что сложившаяся система межличностных отношений не может способствовать эффективному достижению целей группы и поэтому начинается перестройка групповой структуры;

- Стадия нормализации - выстраивание инструментальной системы отношений, направленной на достижение результата;

- Стадия исполнения - устойчивое функционирование группы. 


\section{Рекомендуемая литература для самоподготовки}

Гуревич, П. С. Психология : учебник для вузов / П. С. Гуревич. - 2-е изд., перераб. и доп. - Москва : Издательство Юрайт, 2020. - 465 с. (Высшее образование). - ISBN 978-5-9916-5042-7. - Текст : электронный // ЭБС Юрайт [сайт]. — URL: https://urait.ru/bcode/449915

Лебедев, А. Н. Психология для экономистов : учебник и практикум для вузов / А. Н. Лебедев. - Москва : Издательство Юрайт, 2020. - 328 с. (Высшее образование). - ISBN 978-5-9916-5093-9. — Текст : электронный // ЭБС Юрайт [сайт]. — URL: https://urait.ru/bcode/450257

Психология : учебник и практикум для вузов / А. С. Обухов [и др.] ; под общей редакцией А. С. Обухова. - 2-е изд., перераб. и доп. - Москва : Издательство Юрайт, 2020. - 404 c. - (Высшее образование). ISBN 978-5-534-00631-5. - Текст : электронный // ЭБС Юрайт [сайт]. URL: https://urait.ru/bcode/449860

\section{Задания для самостоятельной работы}

1. Приведите примеры проявления групповых эффектов.

2. Оцените реальную социальную группу, в состав которой вы входите (учебная, организационная) и укажите стадию ее развития, обоснуйте свой ответ.

3. Согласны ли вы с тезисом: «Малая группа является базовой единицей функционирования общества», обоснуйте свой ответ. 


\title{
ПСИХОЛОГИЯ ОБЩЕНИЯ
}

Общение всегда протекает в группе.

Общение процесс динамический.

\begin{abstract}
А.А. Леонтьев Общение - процесс установления и поддержания целенаправленного, прямого или опосредованного теми или иными средствами, контакты с людьми.
\end{abstract}

Принципы исследования общения

1. Рубинштейн С.Л.: Общение есть субъект - субъектные отношения.

$$
\mathrm{S}-\mathrm{S}
$$

2. Процессуальность, непрерывность и динамичность общения. (причины возникновения, этапы и результаты общения).

3. Индивидуализированность - как параметр общения. (уровень потребности в общении, локализованность и интенсивность, проблема коммуникативной активности и наличие установок, навыки и умения).

4. Как вид деятельности (её сторона или специфическая форма).

Классификация по содержанию

1. Материальное - содержанием выступают продукты и предметы деятельности (Бартер).

2. Когнитивное общение предполагает обмен знаниями.

3. Кондиционное общение - обмен психологическими и физиологическими состояниями (рукопожатие, подзатыльник и т.д.).

4. Мотивационное общение - обмен побуждениями, целями мотивами.

5. Деятельностное общение - обмен действиями, операциями, навыками и умениями (мама учит дочь варить кашу).

Классификация по целям общения

1. Биологическое общение (общение необходимое для сохранения и развития организма, удовлетворение базовых потребностей). 
2. Социальное общение (общение, которое преследует цели расширения межличностных контактов, установление и развитие межличностных отношений, становление личности и личностный рост индивида).

Классификация по средствам

1. Опосредованное - непосредственное (использование специальных средств и орудий для организации общения и обмена информацией: технические средства, бумага; Непосредственное - естественные органы речи человека).

2. Прямое - косвенное (прямое - личный контакт друг с другом в процессе общения; косвенное - через посредников, других людей).

Другие классификации

1. Деловое (включено в какую-либо совместную деятельность людей; Содержание - то чем заняты люди, а не проблемы внутреннего мира).

2. Личностное (сосредоточенно на проблемах личностного характера).

$* * *$

1. Личностное (без ролей).

2. Ролевое (с позиции какой либо роли).

$* * *$

1. Светское - пустая болтовня.

2. Деловое - приносящее какую-либо выгоду (содержание - важные события).

$* * *$

1. Инструментальное (вид общения которое не является самоцелью, не стимулируется самостоятельной потребностью и преследует цель кроме удовлетворения потребности в общении).

2. Целевое (цель - удовлетворение потребности в общении). 
1. Вербальное (при помощи речи, языка).

2. Невербальное (при помощи мимики, тактильных, пространственных систем).

\section{Массовая коммуникация}

Коммуникация по направленности сигналов:

1. Аксиальные коммуникативные процессы (Acsis - ось). Процесс передачи информации от одного отправителя к одному получателю. Единичный получатель информации

2. Ретиальные коммуникативные процессы (Rete - сеть) От отправителя большому числу вероятностных получателей.

- В ходе данных коммуникативных процессов происходит социальная ориентация участников процесса, а не только передача информации.

- Обращенность высказывания коллективная а не личностная.

- Задача социальных установок среди широкого круга лиц (двухэтапность)

a) восприятие информации - главная роль - отправитель

б) Интерпретация информации - лидер мнений.

- Отсроченность или почти полное отсутствие обратной связи.

- Фильтры массовой коммуникации - искажают информацию.

Фильтры доверия или недоверия: Они могут быть преодолены с помощью специальных средств: фасцинаций.

/- Ритм сообщения, чем выше ритмичность, тем легче оно доходит до получателя.

/- Музыкальное сопровождение речи (интонация речи вообще).

/- Пространственное сопровождение речи и цветовое. 
/- Семантическая фасцинация. Текст сообщения в определенных условиях оказывается, жизненно важным вызывая резкое изменение в поведении получателей.

Фасцинации широко используются в массовой коммуникации.

На действие фасцинаций влияют: пол, возраст, образование.

Стороны общения:

Коммуникативная - передача информации;

Интерактивная - взаимодействие;

Перцептивная - восприятие человека в процессе общения.

\section{Рекомендуемая литература для самоподготовки}

Гуревич, П. С. Психология : учебник для вузов / П. С. Гуревич. - 2-е изд., перераб. и доп. - Москва : Издательство Юрайт, 2020. - 465 с. (Высшее образование). - ISBN 978-5-9916-5042-7. — Текст : электронный // ЭБС Юрайт [сайт]. — URL: https://urait.ru/bcode/449915

Лебедев, А. Н. Психология для экономистов : учебник и практикум для вузов / А. Н. Лебедев. - Москва : Издательство Юрайт, 2020. - 328 с. (Высшее образование). - ISBN 978-5-9916-5093-9. — Текст : электронный // ЭБС Юрайт [сайт]. — URL: https://urait.ru/bcode/450257

Психология : учебник и практикум для вузов / А. С. Обухов [и др.] ; под общей редакцией А. С. Обухова. - 2-е изд., перераб. и доп. - Москва : Издательство Юрайт, 2020. - 404 c. - (Высшее образование). ISBN 978-5-534-00631-5. — Текст : электронный // ЭБС Юрайт [сайт]. URL: https://urait.ru/bcode/449860

Задания для самостоятельной работы 
1. Дополнительно изучите тему «манипуляции в общении», приведите примеры манипуляций из вашей повседневной жизни.

2. Раскройте содержание коммуникативной, интерактивной и перцептивной сторон общения.

3. Сформулируйте основные принципы эффективного общения в сфере вашей (настоящей, будущей) профессиональной деятельности. 


\section{ЦИТИРУЕМАЯ ЛИТЕРАТУРА}

1. Большой психологический словарь / [Авдеева Н. Н. и др.] ; под ред. Б. Г. Мещерякова, В. П. Зинченко. - 4-е изд., расш. - Москва : АСТ ; Санкт-Петербург : Прайм-Еврознак, 2009. - 811 с.

2. $\quad$ Гиппенрейтер Ю. Б. Введение в общую психологию. Курс лекций. - М.: «ЧеРо», при участии издательства «Юрайт», 2002. - 336 с.

3. Додонов Б. И. Эмоция как ценность. М., Политиздат, 1978. 272 с.

4. Дружинин В. Н. Экспериментальная психология - СПб: Издательство «Питер», $2000-320$ с.

5. Изард К.Э. Психологи я эмоций. - СПб.: Питер, 2012 . - 464 с.

6. Ильин Е. П. Мотивация и мотивы. - СПб.: Питер, $2002-512$ с.

7. Маклаков А. Г. Общая психология. - СПб.: Питер, 2001. - 592 с.

8. Салтыков-Щедрин М.Е. Собрание сочинений в 20 тт. Т. 12.

9. Симонов П.В. Мотивированный мозг. М.: Наука, 1987. 238 с. 


\section{ДОПОЛНИТЕЛЬНАЯ ЛИТЕРАТУРА}

\section{Общая психология}

1. Абрамова, Г.С. Общая психология: Учебное пособие / Г.С. Абрамова. М.: Инфра-М, 2011. - 320 с.

2. Абрамова, Г.С. Общая психология / Г.С. Абрамова. - М.: Академический проект, 2003. - 496 с.

3. Глуханюк, Н.С. Общая психология / Н.С. Глуханюк. - М.: Academia, 2016. - 608 c.

4. Глуханюк, Н.С. Общая психология: Учебное пособие / Н.С. Глуханюк. - М.: Академия, 2017. - 272 с.

5. Еникеев, М.И. Общая и социальная психология: Учебник / М.И. Еникеев. - М.: Норма, НИЦ Инфра-М, 2013. - 640 с.

6. Еникеев, М.И. Общая психология: Учебник для ВУЗов / М.И. Еникеев. - М.: Приор, 2002. - 400 с.

7. Еникеев, М.И. Общая и социальная психология. Энциклопедия (Формат А4) / М.И. Еникеев. - М.: Приор, 2002. - 560 с.

8. Еникеев, М.И. Общая и социальная психология: Учебник / М.И. Еникеев. - М.: Норма, 2019. - 224 с.

9. Еникеев, М.И. Общая и социальная психология: Учебник / М.И. Еникеев. - М.: Норма, 2017. - 176 с.

10. Ерчак, Н.Т. Общая психология. Тестовые задания / Н.Т. Ерчак. Минск: Новое знание, 2005. - 272 с.

11. Иванников, В.А. Общая психология: Учебник для академического бакалавриата / В.А. Иванников. - Люберцы: Юрайт, 2016. - 480 с.

12. Котова, И.Б. Общая психология: Учебное пособие / И.Б. Котова, О.С. Канаркевич. - М.: Дашков и К, Академцентр, 2013. - 480 с. 
13. Крысько, В.Г. Общая психология в схемах и комментариях: Учебное пособие / В.Г. Крысько. - М.: Вузовский учебник, 2019. - 336 с.

14. Крысько, В.Г. Общая психология в схемах и комментариях: Учебное пособие / В.Г. Крысько. - М.: Вузовский учебник, 2017. - 336 с.

15. Макарова, И.В. Общая психология: Краткий курс лекций / И.В. Макарова. - М.: Юрайт, 2013. - 182 с.

16. Макарова, И.В. Общая психология: Учебное пособие для СПО / И.В. Макарова. - Люберцы: Юрайт, 2016. - 182 с.

17. Маклаков, А. Общая психология / А. Маклаков. - СПб.: Питер, 2019. $583 \mathrm{c}$.

18. Маклаков, А.Г. Общая психология: Учебник для вузов / А.Г. Маклаков. - СПб.: Питер, 2013. - 583 с.

19. Маклаков, А.Г. Общая психология / А.Г. Маклаков. - СПб.: Питер, 2019. - 583 c.

20. Маклаков, А.Г. Общая психология. / А.Г. Маклаков. - СПб.: Питер, 2012. - 583 c.

21. Маклаков, А.Г. Общая психология: Учебник / А.Г. Маклаков. - СПб.: Питер, 2014. - 416 с.

22. Марцинковская, Т.Д. Общая психология: Учебное пособие / Т.Д. Марцинковская. - М.: Академия, 2014. - 160 с.

23. Марцинковская, Т.Д. Общая и экспериментальная психология: Учебник / Т.Д. Марцинковская. - М.: Академия, 2014. - 272 с.

24. Мирошниченко, И.В. ВПС: Общая психология / И.В. Мирошниченко. - М.: А-Приор, 2007. - 96 с.

25. Недбаева, С.В. Современный педагог: общая психология / С.В. Недбаева, А.В. Качалова, И.А. Таслова. - М.: Русайнс, 2013. - 320 с. 
26. Немов, Р.С. Общая психология. В 3-х т. Т. 3. Психология личности: Учебник / Р.С. Немов. - М.: Юрайт, 2012. - 739 с.

27. Немов, Р.С. Общая психология. В 3-х т.Общая психология: Учебник / Р.С. Немов. - М.: Юрайт, 2012. - 2472 с.

28. Немов, Р.С. Общая психология в $3 \mathrm{x}$ тт. том іiі: психология личности: Учебник и практикум для академического бакалавриата / Р.С. Немов. Люберцы: Юрайт, 2015. - 739 с.

29. Немов, Р.С. Общая психология в 3x тт. том іi в 4 книгах. книга 4. речь. психические состояния: Учебник и практикум для академического бакалав / Р.С. Немов. - Люберцы: Юрайт, 2016. - 223 с.

30. Немов, Р.С. Общая психология в 3 х тт. том ii в 4 книгах. книга 3. воображение и мышление: Учебник и практикум для академического бакалавриата / Р.С. Немов. - Люберцы: Юрайт, 2016. - 224 с.

31. Немов, Р.С. Общая психология в 3 х тт. том ii в 4 книгах. книга 2. внимание и память: Учебник и практикум для академического бакалавриата / P.С. Немов. - Люберцы: Юрайт, 2016. - 261 с.

32. Немов, Р.С. Общая психология в 3 х тт. том і. введение в психологию: Учебник для бакалавров / Р.С. Немов. - Люберцы: Юрайт, 2016. - 726 с.

33. Немов, Р.С. Общая психология в 3 т. том 2 в 4 кн.. книга 1. ощущения и восприятие: Учебник и практикум для академического бакалавриата / P.С. Немов. - Люберцы: Юрайт, 2016. - 302 с.

34. Нуркова, В.В. Общая психология: Учебник / В.В. Нуркова, Н.Б. Березанская. - Люберцы: Юрайт, 2016. - 524 с.

35. Рамендик, Д.М. Общая психология и психологический практикум / Д.М. Рамендик.. - М.: Форум, 2013. - 304 с.

36. Резепов, И.Ш. Шпаргалки: общая психология / И.Ш. Резепов. - Рн/Д: Феникс, 2018. - 288 с. 
37. Резепов, И.Ш. Шпаргалки: общая психология / И.Ш. Резепов. - РнД: Феникс, 2015. - 128 с.

38. Рогов, Е.И. Общая психология: Курс лекций для первой ступени педагогического образования / Е.И. Рогов. - М.: Владос, 2007. - 447 с.

39. Фаликман, М.В. Общая психология: В 7 т.Т. 4: Учебник / М.В. Фаликман. - М.: Академия, 2008. - 240 с.

40. Човдырова, Г.С. Клиническая психология. Общая часть: Учебное пособие / Г.С. Човдырова, Т.С. Клименко. - М.: Юнити, 2010. - 247 с.

41. Шадриков, В.Д. Общая психология: Учебник для академического бакалавриата / В.Д. Шадриков, В.А. Мазилов. - Люберцы: Юрайт, 2016. - 411 с.

42. Шамхалова, С.Ш. Счастливый билет. Общая психология. Сдаем без проблем / С.Ш. Шамхалова. - М.: Приор, 2007. - 80 с.

43. Штейнмец, А.Э. Общая психология: Учебное пособие / А.Э. Штейнмец. - М.: Академия, 2018. - 496 с.

\section{Социальная психология}

1. Социальная психология: Учебное пособие / Под ред. А.Н. Сухова. М.: Юнити, 2011. - 615 c.

2. Социальная психология: Учебник / Под ред. А.М. Столяренко. - М.: Юнити, 2014. - 511 с.

3. Социальная психология: Учебник / Под ред. А.М. Столяренко. - М.: Юнити, 2012. - 511 с.

4. Социальная психология. Учебник / Под ред. А.М. Столяренко. - М.: Юнити, 2010. - 240 с.

5. Социальная психология. (ВПО). / Под ред. Сухова А.Н., Деркача А.А. M.: Academia, 2019. - 162 c. 
6. Социальная психология для бакалавров: Учебник / Под ред. Руденко А.М.. - Рн/Д: Феникс, 2018. - 223 с.

7. Социальная психология: Учебное пособие / Под ред. А.Н. Сухова. М.: Юнити, 2014. - 615 с.

8. Абраменкова, В.В. Социальная психология детства: Учебник / В.В. Абраменкова. - М.: Инфра-М, 2019. - 272 с.

9. Абраменкова, В.В. Социальная психология детства: Уч. / В.В. Абраменкова. - М.: Инфра-М, 2018. - 160 с.

10. Алтунина, И.Р. Социальная психология: Учебник / И.Р. Алтунина, P.С. Немов. - Люберцы: Юрайт, 2015. - 427 с.

11. Андреева, Г.М. Социальная психология в современном мире / Г.М. Андреева, А.И. Донцова. - М.: Аспект-Пресс, 2002. - 335 с.

12. Андреева, Г.М. Социальная психология: Учебник для высших учебных заведений / Г.М. Андреева. - М.: Аспект Пресс, 2012. - 363 с.

13. Андреева, Г.М. Социальная психология: Учебник / Г.М. Андреева. М.: Аспект-Пресс, 2016. - 363 с.

14. Андриенко, Е.В. Социальная психология: Учебное пособие для студ. учреждений высш. проф. образования / Е.В. Андриенко . - М.: ИЦ Академия, 2012. - 264 c.

15. Андриенко, Е.В. Социальная психология / Е.В. Андриенко. - М.: Academia, 2018. - 320 c.

16. Андриенко, Е.В. Социальная психология: Учебное пособие / Е.В. Андриенко. - М.: Академия, 2014. - 480 с.

17. Белинская, Е.П. Социальная психология: Хрестоматия / Е.П. Белинская, О.А. Тихомандрицкая. - М.: Аспект-Пресс, 2012. - 456 с.

18. Белинская, Е.П. Социальная психология личности: Учебное пособие / Е.П. Белинская. - М.: Академия, 2015. - 304 с. 
19. Веракса, Н.Е. Социальная психология: Учебник для студ. учреждений высш. проф. образования / Н.Е. Веракса, А.Н. Веракса. - М.: ИЦ Академия, 2011. - 224 с.

20. Веракса, Н.Е. Социальная психология: учебник / Н.Е. Веракса. - М.: Academia, 2016. - $352 \mathrm{c}$.

21. Веракса, Н.Е. Социальная психология: Учебник / Н.Е. Веракса. - М.: Академия, 2018. - 176 с.

22. Гераськина, М.Г. Социальная психология: Учебное пособие для студентов вузов / А.Н. Сухов, М.Г. Гераськина, А.М. Лафуткин; Под ред. А.Н. Сухов. - М.: Юнити-Дана, 2011. - 615 с.

23. Гулевич, О.А. Социальная психология справедливости: Бизнес, политика, юриспруденция. / О.А. Гулевич. - М.: Аспект-Пресс, 2007. - 254 с.

24. Гулевич, О.А. Социальная психология справедливости / О.А. Гулевич. - М.: Институт психологии РАН, 2011. - 284 с.

25. Гулевич, О.А. Социальная психология: Учебник и практикум для академического бакалавриата / О.А. Гулевич, И.Р. Сариева. - Люберцы: Юрайт, 2015. - 452 с.

26. Гулевич, О.А. Социальная психология: Учебник и практикум для академического бакалавриата / О.А. Гулевич, И.Р. Сариева. - Люберцы: Юрайт, 2016. - 452 с.

27. Денисова, Ю.В. Социальная психология: Учебное пособие / Ю.В. Денисова, Е.Т. Имашева. - М.: Омега-Л, 2011. - 172 с.

28. Денисова, Ю.В. Социальная психология. / Ю.В. Денисова, Е.Т. Имашева. - М.: Омега-Л, 2018. - 64 с.

29. Дикая, Л.Г. Социальная психология труда: Теория и практика. Т. 2 / Л.Г. Дикая, А.Л. Журавлев. - М.: Институт психологии РАН, 2010. - 442 с. 
30. Дикая, Л.Г. Социальная психология труда: Теория и практика. Т. 1 / Л.Г. Дикая, А.Л. Журавлев. - М.: Институт психологии РАН, 2010. - 488 с.

31. Донцов, Д.А. Социальная психология / Д.А. Донцов, А.А. Денисов, Л.В. Сенкевич. - М.: Человек, 2010. - 80 с.

32. Дридзе, Т.М. Язык и социальная психология / Т.М. Дридзе. - М.: КД Либроком, 2009. - 240 с.

33. Еникеев, М.И. Общая и социальная психология: Учебник / М.И. Еникеев. - М.: Норма, НИЦ Инфра-М, 2013. - 640 с.

34. Еникеев, М.И. Общая и социальная психология: Учебник / М.И. Еникеев. - М.: Норма, 2017. - 176 с.

35. Еникеев, М.И. Общая и социальная психология. Энциклопедия (Формат А4) / М.И. Еникеев. - М.: Приор, 2002. - 560 с.

36. Еникеев, М.И. Общая и социальная психология: Учебник / М.И. Еникеев. - М.: Норма, 2019. - 224 с.

37. Ефимова, Н.С. Социальная психология: Учебное пособие / Н.С. Ефимова. - М.: ИД Форум, НИЦ Инфра-М, 2013. - 192 с.

38. Ефимова, Н.С. Социальная психология: Учебник для бакалавров / Н.С. Ефимова, А.В. Литвинова. - М.: Юрайт, 2012. - 442 с.

39. Ефимова, Н.С. Социальная психология: Учебник для бакалавров / Н.С. Ефимова, А.В. Литвинова. - Люберцы: Юрайт, 2016. - 442 с.

40. Ефимова, Н.С. Социальная психология: Учебник для СПО / Н.С. Ефимова, А.В. Литвинова. - Люберцы: Юрайт, 2016. - 442 с.

41. Ефимова, Н.С. Социальная психология: Учебное пособие / Н.С. Ефимова. - М.: Форум, 2017. - 496 с.

42. Журавлев, А.Л. Социальная психология российского предпринимательства: Концепция психологических отношений / А.Л. Журавлев, В.П. Позняков. - М.: ИП РАН, 2012. - 480 с. 
43. Журавлев, А.Л. Социальная психология: Учебное пособие / А.Л. Журавлев, В.А. Соснин, М.А. Красников. - М.: Форум, 2011. - 496 с.

44. Журавлев, А.Л. Социальная психология: Учебное пособие / А.Л. Журавлев, В.А. Соснин, М.А. Красников. - М.: Форум, 2019. - 184 с.

45. Корягина, Н.А. Социальная психология. теория и практика: Учебник для бакалавров / Н.А. Корягина, Е.В. Михайлова. - Люберцы: Юрайт, 2016. $492 \mathrm{c}$.

46. Корягина, Н.А. Социальная психология. Теория и практические методы: Учебник / Н.А. Корягина. - Люберцы: Юрайт, 2016. - 316 с.

47. Кричевский, Р.Л. Социальная психология малой группы. / Р.Л. Кричевский, Е.М Дубовская. - М.: Аспект-Пресс, 2009. - 318 с.

48. Крушельницкая, О.Б. Социальная психология образования: Учебное пособие / О.Б. Крушельницкая. - М.: Вузовский учебник, 2019. - 336 с.

49. Крушельницкая, О.Б. Социальная психология обр.: Учебное пособие / О.Б. Крушельницкая, О.Б. Крушельницкая, М. Сачкова. - М.: Вузовский учебник, 2018. - 336 с.

50. Крысько, В.Г. Социальная психология. Курс лекций: Учебное пособие / В.Г. Крысько. - М.: Вузовский учебник, Инфра-М, 2012. - 256 с.

51. Крысько, В.Г. Социальная психология: Учебник для бакалавров / В.Г. Крысько. - Люберцы: Юрайт, 2016. - 553 с.

52. Крысько, В.Г. Социальная психология в схемах и комментариях: Учебное пособие / В.Г. Крысько. - М.: Вузовский учебник, 2018. - 448 с.

53. Крысько, В.Г. Социальная психология. Курс лекций: Учебное пособие / В.Г. Крысько. - М.: Вузовский учебник, 2015. - 332 с.

54. Крысько, В.Г. Социальная психология. Курс лекций: Учебное пособие / В.Г. Крысько. - М.: Вузовский учебник, 2017. - 64 с. 
55. Майерс, Д. Социальная психология / Д. Майерс. - СПб.: Питер, 2012. $416 \mathrm{c}$.

56. Майерс, Д. Социальная психология / Д. Майерс. - СПб.: Питер, 2016. $800 \mathrm{c}$.

57. Майерс, Д. Социальная психология / Д. Майерс. - СПб.: Питер, 2013. $800 \mathrm{c}$.

58. Майерс, Д. Социальная психология / Д. Майерс; Пер. с англ. 3.С. Замчук.. - СПб.: Питер, 2013. - 800 с.

59. Майерс, Д. Социальная психология / Д. Майерс. - СПб.: Питер, 2018. $800 \mathrm{c}$.

60. Мельникова, Н.А. Социальная психология / Н.А. Мельникова. - М.: Рипол-классик, 2017. - 160 с.

61. Милованов, В.П. Синергетика и самоорганизация: Социальная психология / В.П. Милованов. - М.: КД Либроком, 2013. - 184 с.

62. Морозов, А.В. Социальная психология: Учебник / А.В. Морозов. М.: Академический проект, 2013. - 335 с.

63. Морозов, А.В. Социальная психология / А.В. Морозов. - М.: Академический проект, 2008. - 335 с.

64. Немов, Р.С. Социальная психология: Учебное пособие / Р.С. Немов. СПб.: Питер, 2010. - 432 с.

65. Немов, Р.С. Социальная психология: Учебное пособие / Р.С. Немов, И.Р. Алтунина. - СПб.: Питер, 2010. - 432 с.

66. Реан, А.А. Социальная педагогическая психология / А.А. Реан. СПб.: Прайм-Еврознак, 2008. - 576 с.

67. Руденко, А.М. Социальная психология для бакалавров: учебник / А.М. Руденко. - РнД: Феникс, 2016. - 332 с. 
68. Самойлов, В.Д. Педагогическая антропология: Учебник для студентов вузов, обучающихся по специальностям " Педагогика и психология девиантного поведения", "Социальная педагогика", "Психология служебной деятельности" / В.Д. Самойлов. - М.: Юнити-Дана, Закон и право, 2013. - 271 с.

69. Свенцицкий, А.Л. Социальная психология общения: Монография / А.Л. Свенцицкий, В.Н. Панфёров, Л.В. Куликов и др. - М.: Инфра-М, 2017. - 64 c.

70. Свенцицкий, А.Л. Социальная психология: Учебник для бакалавров / А.Л. Свенцицкий. - Люберцы: Юрайт, 2016. - 408 с.

71. Сидоренков, А.В. Социальная психология малых групп: Учебное пособие / А.В. Сидоренков. - Рн/Д: Феникс, 2012. - 381 с.

72. Соснин, В.А. Социальная психология: Уч. / В.А. Соснин, Е.А. Красникова. - М.: Форум, 2013. - 32 с.

73. Соснин, В.А. Социальная психология: Учебник / В.А. Соснин, Е.А. Красникова. - М.: Форум, 2013. - 336 с.

74. Столяренко, Л.Д. Социальная психология: Краткий курс лекций / Л.Д. Столяренко, В.Е. Столяренко. - М.: Юрайт, 2012. - 219 с.

75. Столяренко, Л.Д. Социальная психология: Учебное пособие для прикладного бакалавриата / Л.Д. Столяренко, В.Е. Столяренко. - Люберцы: Юрайт, 2016. - 219 с.

76. Столяренко, Л.Д. Социальная психология: Учебное пособие / Л.Д. Столяренко, С.И. Самыгин. - М.: Дашков и К, 2016. - 240 с.

77. Столяренко, Л.Д. Социальная психология: Для студентов вузов / Л.Д. Столяренко, С.И. Самыгин. - Рн/Д: Феникс, 2009. - 251 с.

78. Столяренко, Л.Д. Социальная психология: Учебное пособие для бакалавров / Л.Д. Столяренко, С.И. Самыгин. - М.: Дашков и К, 2016. - 240 с. 
79. Столяренко, Л.Д. Социальная психология (для бакалавров) / Л.Д. Столяренко, С.И. Самыгин. - М.: КноРус, 2018. - 80 с.

80. Столяренко, Л.Д. Социальная психология: Учебное пособие для СПО / Л.Д. Столяренко. - Люберцы: Юрайт, 2016. - 219 с.

81. Сухов, А.Н. Социальная психология: Учебное пособие / А.Н. Сухов. М.: Академия, 2012. - 192 с.

82. Сухов, А.Н. Социальная психология: Учебное пособие / А.Н. Сухов. М.: Академия, 2008. - 336 с.

83. Сухов, А.Н. Социальная психология: Учебное пособие для студентов учреждений среднего профессионального образования / А.Н. Сухов . - М.: ИЦ Академия, 2013. - 240 с.

84. Сухов, А.Н. Социальная психология. (СПО). / А.Н. Сухов. - М.: Academia, 2007. - $159 \mathrm{c}$.

85. Сухов, А.Н. Социальная психология: Учебное пособие / А.Н. Сухов, М.Г. Гераськина. - М.: Юнити, 2016. - 224 с.

86. Сухов, А.Н. Социальная психология организованной преступности: Монография / А.Н. Сухов. - М.: Юнити, 2014. - 623 с.

87. Сухов, А.Н. Социальная психология: Учебное пособие / А.Н. Сухов. M.: Academia, 2018. - 208 c.

88. Цветкова, Л.А. Социальная психология наркотизма в студенческой среде / Л.А. Цветкова. - СПб.: СПбГУ, 2012. - 256 с.

89. Чалдини, Р. Социальная психология / Р. Чалдини. - СПб.: Питер, 2016. - 848 c.

90. Шипунов, В.Г. Основы управленческой деятельности: Социальная психология, менеджмент. / В.Г. Шипунов. - М.: Высшая школа, 2004. - 327 с.

91. Шуванов, В.И. Социальная психология управления: Учебник / В.И. Шуванов. - М.: Юнити, 2013. - 463 с. 
92. Шуванов, В.И. Социальная психология управления: Учебник / В.И. Шуванов. - М.: Юнити, 2014. - 463 с.

93. Шуванов, В.И. Социальная психология управления: Учебник для студентов вузов, обучающихся по специальностям "Маркетинг", "Коммерция" / В.И. Шуванов. - М.: Юнити-Дана, 2013. - 463 с.

94. Юревич, А.В. Социальная психология научной деятельности / А.В. Юревич. - М.: Институт психологии РАН, 2013. - 447 с. 


\section{Основы психологии}

\section{(учебное пособие для непрофильных специальностей)}

Автор-составитель: Д.Н. Долганов

Книга издана в авторской редакичии.

Дизайн обложки: Р.В. Орлов

Доступ к пособию - свободный.

Режим доступа: http://nkras.ru/arhiv/2021/DolganovDN.pdf

Пособие содержится в едином файле PDF.

Дата выхода в свет 12.03.2021.

Свободная цена. Заказ ОП1203/21.

По вопросам приобретения и издания литературы обращаться по адресу:

Издательство НИЦ

ул. 9 Мая, 5/192, г. Красноярск, 660127 Россия

тел. +7 (923) 358-10-20

Электронная почта: monography@nkras.ru

Дополнительная информация на сайте: www.nkras.ru 
